\title{
40. MAGMATIC DEVELOPMENT OF THE SOUTHEAST GREENLAND MARGIN AND EVOLUTION OF THE ICELAND PLUME: GEOCHEMICAL CONSTRAINTS FROM LEG 152
}

\author{
Andrew D. Saunders, ${ }^{2}$ Hans Christian Larsen, ${ }^{3}$ and J. Godfrey Fitton ${ }^{4}$
}

\begin{abstract}
Leg 152, located on the southeast Greenland Margin, successfully recovered igneous rocks from three drill sites along a transect at $63^{\circ} \mathrm{N}: 915,917$, and 918 . The margin is characterized by a $150-\mathrm{km}$-wide sequence of seaward-dipping reflectors (SDRS), and thus has an architecture typical of volcanic rifted margins. Site 917 was located close to the inboard, feather-edge of the SDRS, on the continental shelf, and drilling recovered rocks ranging in composition from picrite to dacite. Site 915 was immediately oceanward of Site 917, and Site 918 was located on the continental rise, in the main sequence of the SDRS. Drilling at both Sites 915 and 918 recovered basalt. Ash horizons were cored in the sediment column at Site 918 and Site 919 in the Irminger Basin. The oldest recovered lavas (the Lower and Middle Series from Site 917), erupted approximately 61 m.y. ago, sit on steeply dipping pre-rift metasediments. They are variably contaminated by ancient amphibolite- and granulite-facies crust, consistent with eruption in a continental setting before plate breakup. A few of the Lower Series lavas are high-MgO basalts. The amount of contamination decreased dramatically in the succeeding Upper Series lavas, which also show evidence for a rapid shallowing of the average depth of melting, and contain a high proportion of picrites and high-MgO basalts. These observations are consistent with attenuation of the lithosphere and rapid egress of magmas to the surface during eruption of the Upper Series lavas. Basalt from Site 915 is only slightly contaminated by continental crust, and basalts from Site 918, erupted during C24r time (approximately 56-53 Ma), are uncontaminated.

The eruption environment and the composition of the lavas indicate a clear role for the Iceland plume, in that (1) some lava flows from the Lower and Upper Series at Site 917 represent high-MgO magmas and, by inference, had high liquidus and source temperatures; (2) the main sequence of the SDRS were erupted subaerially, thus requiring support from hot, buoyant mantle; and (3) the basalts from Sites 915 and 918 more closely resemble depleted Icelandic tholeiites than normal mid-oceanridge basalts. Leg 152 has shown that igneous activity was under way by $61 \mathrm{Ma}$ on the southeast Greenland Margin, at the same time as in West Greenland and the British Isles, over $2000 \mathrm{~km}$ apart in their pre-drift locations.
\end{abstract}

\section{INTRODUCTION}

It has been known for over a decade that thick sequences of lavas occur along some passive margins of ocean basins (e.g., Hinz, 1981; Mutter et al., 1982). As seismic data have accumulated, it has become apparent that these "volcanic rifted margins" are the norm, rather than the exception, at least in the North Atlantic (Fig. 1), and that the thick lava piles (characterized by seaward-dipping reflector sequences or SDRS) are complemented by prisms of underplated igneous material in the middle and lower crust (White et al., 1987; Larsen and Jakobsdóttir, 1988; Mutter et al., 1988; Coffin and Eldholm, 1992, 1994). The total igneous crustal thickness along these margins may be as much as 15 to $20 \mathrm{~km}$, and may exceed $30 \mathrm{~km}$ adjacent to the Faeroes-Iceland Ridge (e.g., Barton and White, 1995). This is of a similar magnitude to the thickness of continental crust.

Although several sections of the North Atlantic margins are structurally well characterized (e.g., Hatton and Edoras Banks: Fowler et al., 1989; Morgan et al., 1989; Spence et al., 1989; White, 1992; Faeroes-Iceland Ridge: Bott and Gunnarsson, 1980; Vøring Plateau: Mutter and Zehnder, 1988; Lofoten Basin: Goldschmidt-Rokita et al., 1994; Jameson Land Basin: Larsen and Marcussen, 1992; and the present study area, southeast Greenland: Larsen and Jakobsdóttir, 1988; Larsen et al., Chap. 39, this volume), few samples are available with which to determine the age and environment of eruption, and the composition of the erupted magmas. Prior to 1993, when Leg 152

'Saunders, A.D., Larsen, H.C., and Wise, S.W., Jr. (Eds.), 1998. Proc. ODP, Sci. Results, 152: College Station, TX (Ocean Drilling Program).

${ }^{2}$ Department of Geology, University of Leicester, Leicester LE1 7RH, United Kingdom.ADS@LE.AC.UK

${ }^{3}$ Danish Lithosphere Centre, Østervoldgade 10, L, 1350 Copenhagen K, Denmark.

${ }^{4}$ Department of Geology and Geophysics, King's Buildings, West Mains Road, University of Edinburgh, Edinburgh EH9 3JW, United Kingdom. visited the southeast Greenland Margin, igneous basement had been recovered from the Vøring Margin (Leg 38, Sites 338, 342, and 343: Talwani, Udintsev, et al., 1976; Leg 104, Sites 642 and 643: Eldholm, Thiede, Taylor, et al., 1987), the Rockall Plateau (Hatton Bank) margin (Leg 81, Sites 552-555: Roberts, Schnitker, et al., 1984), and the Faeroes-Iceland Ridge (Leg 38, Site 336: Talwani, Udintsev, et al., 1976) (Fig. 1). Drilling on both the Hatton Bank and Vøring Plateau transects had been particularly successful, recovering long sequences of basalt (and, in the case of Site 642 on the Vøring Plateau, dacite) of Paleocene or Eocene age. The drilling also showed that the basalts were erupted in a subaerial, or shallow marine, environment (Talwani, Udintsev, et al., 1976; Roberts, Schnitker, et al., 1984; Eldholm, Thiede, Taylor, et al., 1987).

Before Leg 152, we also knew that the basalts from the SDRS on Hatton Bank closely resemble mid-ocean-ridge basalts, with lightrare earth element (REE)-depleted compositions (e.g., Joron et al., 1984; Merriman et al., 1988). Basalts from the Vøring Plateau, however, have flat to light-REE-enriched patterns (e.g., Viereck et al., 1989) (Fig. 2), implying different mantle sources and/or different conditions of melting. Contamination of magmas during their ascent through continental crust is a distinct possibility in such transitional environments, however, and must be taken into account before any attempt is made to interpret the source characteristics or melting regime of the erupted lavas. For example, the dacites from the Lower Series at Site 642 on the Vøring Plateau represent crustal melts (e.g., Viereck et al., 1988), and even the light-REE-depleted basalts from Hatton Bank show evidence of crustal contamination (Morton and Taylor, 1987).

The SDRS offer key information about the development of the North Atlantic Igneous Province. This large igneous province (LIP) extended from Baffin Island in the west, to the British Isles in the east, a pre-drift distance of some $2000 \mathrm{~km}$ (Fig. 3). The bulk of the magmas were erupted during the period 62 to $50 \mathrm{Ma}$, although activity continued throughout the Tertiary to form the Faeroes-Greenland 


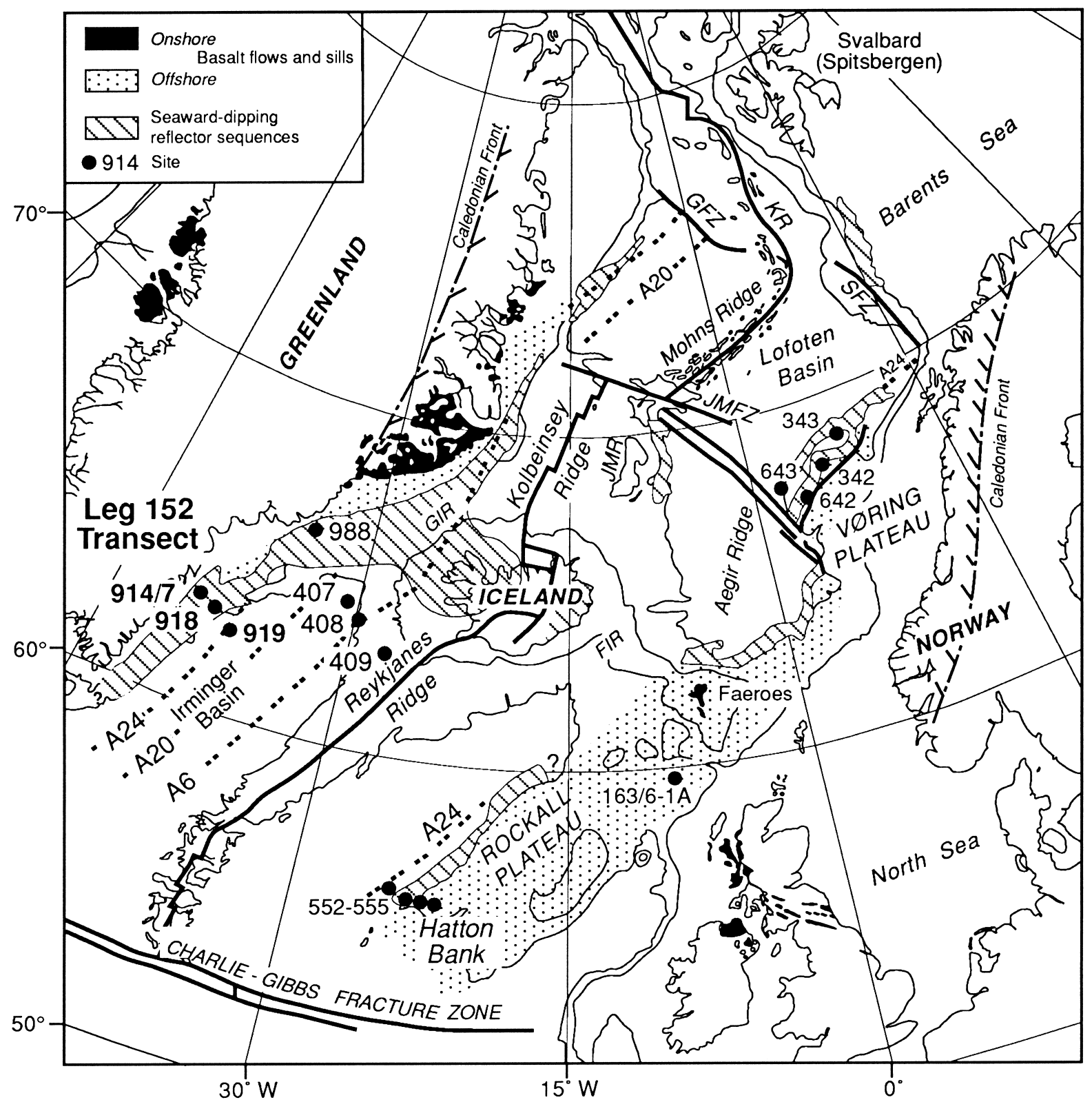

Figure 1. Map of the North Atlantic Ocean and its margins, showing the location of the major physiographic features, major Paleogene igneous sequences, and Deep Sea Drilling Project (DSDP) and Ocean Drilling Program (ODP) basement drill sites relevant to this chapter. Modified after Larsen, Saunders, Clift, et al. (1994). GIR = Greenland-Iceland Ridge; FIR = Faeroes-Iceland Ridge; JMR = Jan Mayen Ridge; JMFZ = Jan Mayen Fracture Zone; GFZ = Greenland Fracture Zone; KR = Kolbeinsey Ridge; SFZ = Senja Fracture Zone.

Ridge and Iceland (e.g., White and McKenzie, 1989; White et al., 1996; Staples et al., in press). It has been argued that the activity occurred during two phases (e.g., Saunders et al., in press); an early, pre-breakup phase (62-58 Ma) when the activity was predominantly continent-based; and a later, syn- and post-breakup phase (approximately 56 Ma to the present day) that accompanied plate separation (initiated in the North Atlantic during Chron C24r time: Vogt and Avery, 1974). The excess magmatism during both phases has been attributed to the Iceland plume, which supplied the bulk of the thermal energy necessary for the production of large volumes of magma (Brooks, 1973; Vink, 1984; White and McKenzie, 1989). The SDRS and the prisms of high-velocity material in the middle and lower crust are the most voluminous portion of the North Atlantic Igneous Province (e.g., White et al., 1987; Eldholm and Grue, 1994); they were erupted during the rifting event, and as such offer a potential record of that critical transition event. Their eruption environment (sub- aerial, shallow aqueous, or deep marine) provides information about the thermal condition of the underlying mantle (e.g., Clift et al., 1995). Furthermore, the SDRS may, in any one segment of the rifted margin, provide the initial melts that are uncontaminated by continental crust, and therefore a snapshot of the chemical composition of the underlying mantle.

Despite the complementary data from onshore basalt sequences and dike swarms in East Greenland, northwest Europe, and Iceland, and despite the success of drilling during Legs 81 and 104, these two drilling transects alone were unable to provide a complete picture of the early development of the volcanic rifted margin. Specific questions include the following:

1. What was the relationship between rifting, magmatism, and breakup? Did rifting precede the onset of magmatism, or were some of the margin magmas erupted before rifting? 

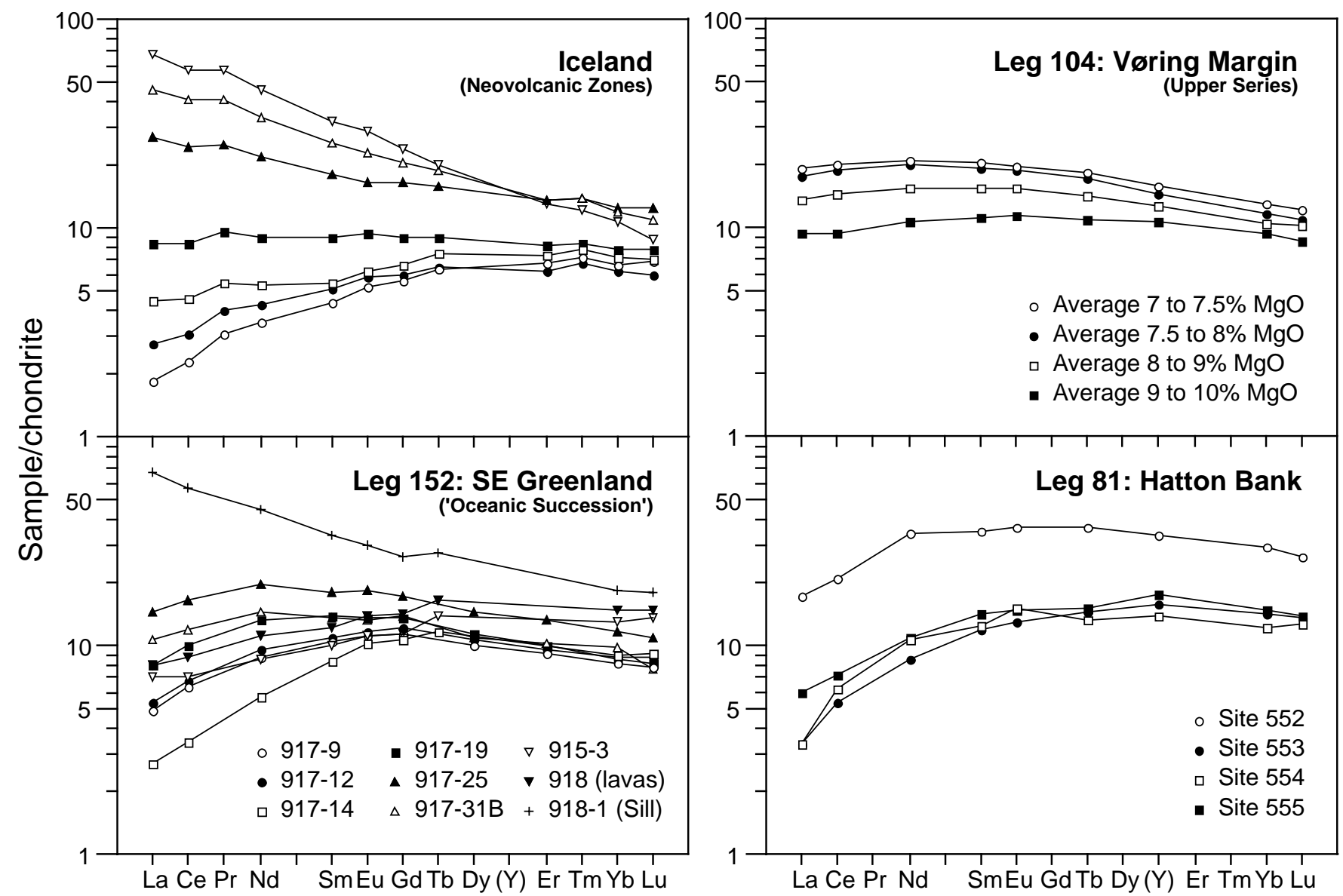

Figure 2. Chondrite-normalized rare-earth-element patterns for basalts from Iceland (neovolcanic zone basalts and picrites grouped according to La/Yb ratios; data from compilation in Hémond et al., 1993); Hatton Bank (ODP Leg 81, average values of basalts from Sites 552 through 555; data from Merriman et al., 1988); Vøring Plateau (ODP Leg 104, Site 642, Upper Series; basalts grouped according to MgO; data from Viereck et al., 1989); southeast Greenland (ODP Leg 152, Sites 917 Upper Series, 915, and 918; individual samples from numbered units are plotted, except for 918, where average value shown; data from Fitton et al., Chap. 28, and Fram et al., both this volume).

2. What was the environment of emplacement of the SDRS? Was it subaerial, implying that the rift and magmatic zone were supported by hot mantle, as in Iceland, or was it deep water, as along normal, nonvolcanic rifted margins? What was the rate of subsidence of the margin?

3. What is the composition of the lavas? To what extent were they contaminated as they passed through the continental lithosphere? To model subsidence accurately it is necessary to know whether or not the lavas were erupted onto continental crust (which could act as a buoyant foundation). If the basalts are uncontaminated, can we estimate the pressure of melting (the depth of melt segregation should decrease as the lithosphere rifts and breaks apart)?

This synthesis chapter will deal mainly with question 3 from the above list; questions 1 and 2 are dealt with by Larsen and Saunders (this volume). We are concerned, primarily, with the contribution from, and the evolution of, the Iceland thermal anomaly, or plume. We accept that the use of the term "plume" need not be synonymous with the term "thermal anomaly." We use the term mantle plume to imply a body of rock that is buoyantly ascending from a boundary layer deep within the mantle. The concept embraces start-up plumes, which have a large, bulbous head and which rise diapirically through the ambient mantle (e.g., Griffiths and Campbell, 1990); steady-state systems, whereby material is fed through a thin feeder conduit to a flattened, mushroom-shaped head (e.g., White and McKenzie, 1989; Kent, 1991); and episodic systems, whereby material rises as a series of blobs from a boundary layer (e.g., Schilling and Noe-Nygaard, 1974; Schilling, 1975). All of these models have been proposed for the North Atlantic system. We initially make no judgment about the temperature of the plume (although it is generally assumed that positive buoyancy is achieved by hotter-than-ambient conditions), about its composition, nor about the location of the boundary layer(s) from which it ascends.

The stipulation that a plume arises from a boundary layer is the main distinction between plumes and mantle "hot cells" proposed by Anderson et al. (1992). These are regions of warmer-than-ambient mantle, caused partly by the insulating effect of the overlying lithosphere (especially thick cratonic lithosphere), and partly by the cooling effect of distant subduction zones. No connection to deeply rooted plumes is required or implied to produce hot cells.

The enhanced convection model of Mutter et al. (1988) requires no thermal anomaly. They argue that the sharp thermal contrast between the cool continental lithosphere and the convective asthenosphere induces local convection cells beneath the developing rift zone. This increases the flux rate of mantle ascending into the melting zone, and thus increases the rate of melt production. As the original plates separate, the vigorous convection cells break down and normal-thickness ocean crust is produced.

The evidence for involvement of a plume in the formation of the North Atlantic Igneous Province is overwhelming. Iceland presently sits on top of a mantle thermal anomaly; the crust is some two to three times thicker than normal ocean crust, and the surface is up to $1 \mathrm{~km}$ above sea level. This almost certainly requires a region of hotter- 

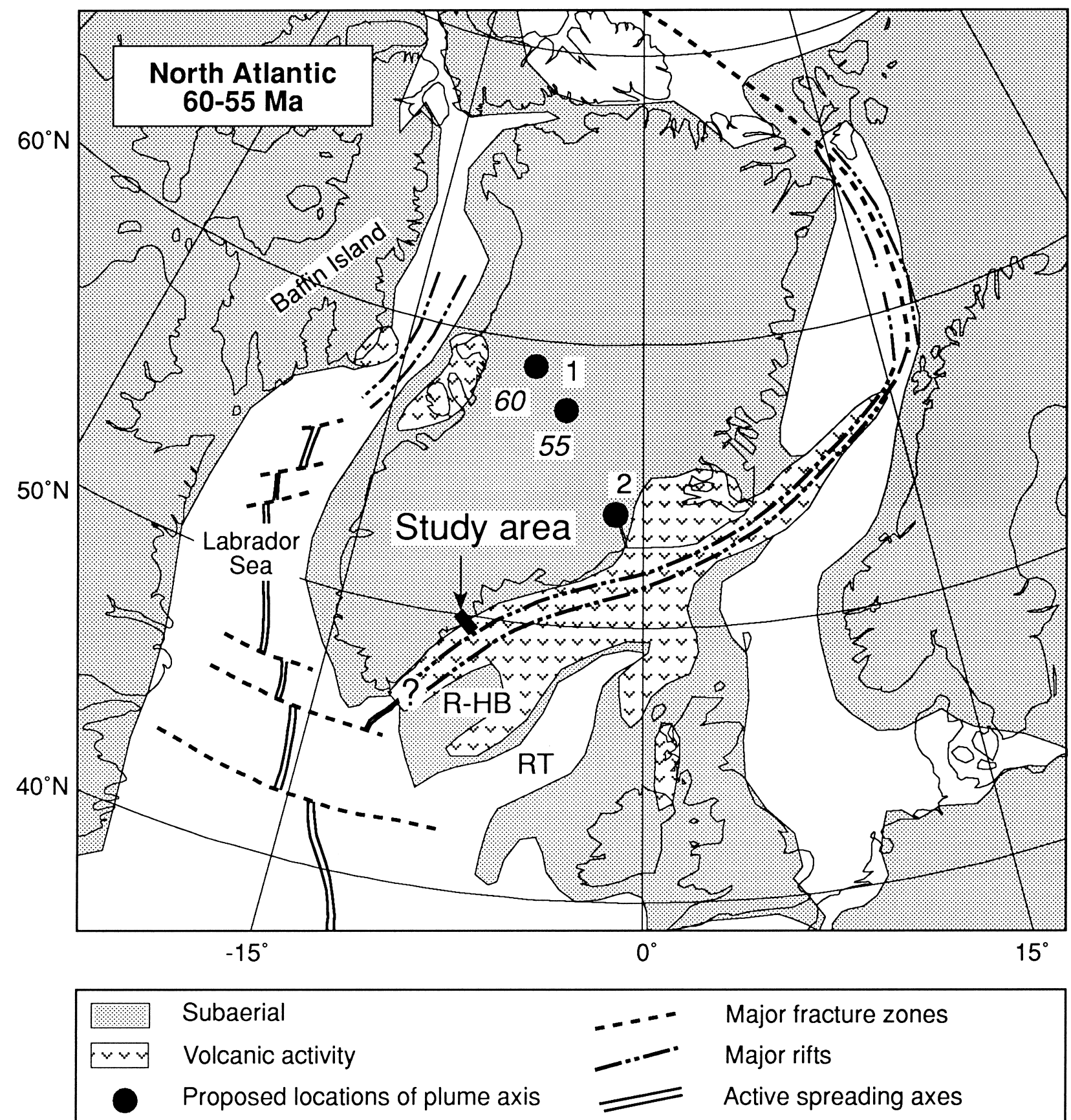

Figure 3. Late Paleocene plate tectonic reconstruction of the North Atlantic region, showing the main physiographic features. Location and extent of the lava sequences are based on knowledge of present-day outcrops; the Paleocene outcrops may have had much greater extent, but have since been removed by erosion. Adapted from Ziegler (1982) and Doré (1991), using a base map supplied by Cambridge Paleomap Services, Cambridge, United Kingdom. Predicted locations of plume axes from Lawver and Müller (1994) (point 1 at 55 and 60 Ma) and White and McKenzie (1989) (point 2). R-HB = Rockall-Hatton Bank; RT = Rockall Trough.

than-ambient mantle, although precisely how much hotter is uncertain (estimates vary from about $100^{\circ} \mathrm{C}$ : Ribe et al., 1995 , to $260^{\circ} \mathrm{C}$ : Schilling, 1991, above ambient). This hot mantle also affords some dynamic support to the Iceland plateau. The plume has recently been imaged using seismic waves (Wolfe et al., 1997) and detected to depths of at least $400 \mathrm{~km}$. Furthermore, the Iceland magmatic anomaly extends back in time to the volcanic margins of Greenland and northwest Europe via the Greenland-Faeroes Ridges, providing strong evidence for continuity of process. More circumstantial evidence for a widespread plume is provided by the Paleogene flood ba- salt sequences in Greenland and northwest Europe, which indicate the onset of igneous activity at about $62 \mathrm{Ma}$, in regions up to $2000 \mathrm{~km}$ apart (Fig. 3).

To address these and other questions, the Ocean Drilling Program established the North Atlantic Rifted Margins Detailed Planning Group (NARM-DPG), which convened twice in 1991. The NARMDPG proposed a program of drilling on the southeast Greenland and the Vøring Margins; Leg 152 was to be the first of these (Larsen et al., 1991). The southeast Greenland Margin, $63^{\circ} \mathrm{N}$, was favored because of (1) its relatively simple tectonic structure; (2) its location ap- 
proximately half way between the axis of the putative, ancestral plume, and the drilled transect on Hatton Bank, which is close to the edge of the plume; (3) scheduled cruises to obtain high-density, highresolution seismic data; and (4) its reasonably predictable ice-free window. Future legs would, it was hoped, build on the data collected during Leg 152, and drill a series of transects closer to the putative plume axis, thus providing a three-dimensional picture of the development of the ancestral thermal/compositional anomaly.

From the above it is apparent that we can extend the list of questions to be addressed by drilling across the southeast Greenland Margin to include the following:

4. Can we identify an Icelandic "plume" signature in the basalts of the SDRS? This would allow us to distinguish between the plume model, and the hot-cell and enhanced convection models that require no contribution from a plume. If, for example, we could demonstrate that all of the basalts came from normal mid-ocean-ridge (N-MORB) asthenosphere, the case for a plume is weakened.

5. Does the short-duration (burst) of voluminous basaltic magmatism so characteristic of many large igneous provinces reflect the arrival and decompression of a hot plume head from the deep mantle (e.g., Richards et al., 1989; Campbell and Griffiths, 1990), or is it a consequence of lithosphere thinning and rupture above a long-lived thermal anomaly? Expressed differently, are magmatic flux rates directly correlated to mantle flux rates?

6. Is the thermal "footprint" of a mantle plume perfectly coincident with its chemical footprint, or are plumes concentrically structured (for example, with a hot aureole of N-MORB-type asthenosphere surrounding a core of material from the deeper mantle)? Ultimately, knowledge of such structures could provide information about the dynamics of mantle plumes; the North Atlantic provides a unique opportunity for such studies.

7. Finally, the tephra recovered in the younger parts of the core offer an opportunity to investigate the temporal evolution of the Iceland plume.

\section{SUMMARY OF IGNEOUS STRATIGRAPHY}

During Leg 152, drilling recovered basement at three of the six sites (Figs. 4, 5, 6; Table 1) (Larsen, Saunders, Clift, et al., 1994). Although the drill sites were too far apart or insufficiently deep to provide a contiguous sequence of lavas from the SDRS, we did recover material with a range of ages. The oldest recovered portion of the SDRS was from the lower part of Hole 917A, where basalts are in contact with underlying metasediments. The youngest part of the SDRS sampled during Leg 152 was at Site 918. Drilling at Site 915 recovered basalt of an intermediate age. A more detailed discussion of the lava stratigraphy is presented by Larsen and Saunders (this volume).

Site 917 , located on the continental shelf and on the feather edge of the SDRS about $50 \mathrm{~km}$ from the Greenland coast, was the most successful in terms of total basement penetration, drilling through $779 \mathrm{~m}$ of lavas and interbedded sediments and into underlying metasediments (Fig. 6). The lavas at this site are the oldest of those drilled during Leg 152. Drilling at Hole 917A reached basaltic basement at 41.9 meters below seafloor (mbsf). Ninety-one flow units, plus one intrusive sheet, were identified in the core, and these have been grouped into three stratigraphic series: an Upper (41.9-183.4 mbsf), a Middle (184.1-376.7 mbsf), and a Lower Series (376.7820.7 mbsf) (Larsen, Saunders, Clift, et al., 1994). The volcanic succession is underlain by a thin sandstone unit, and steeply inclined metasediments that appear to have a significant volcanogenic component (Vallier et al., this volume). At the time of writing we have no clear indication about the age or provenance of these sediments (a

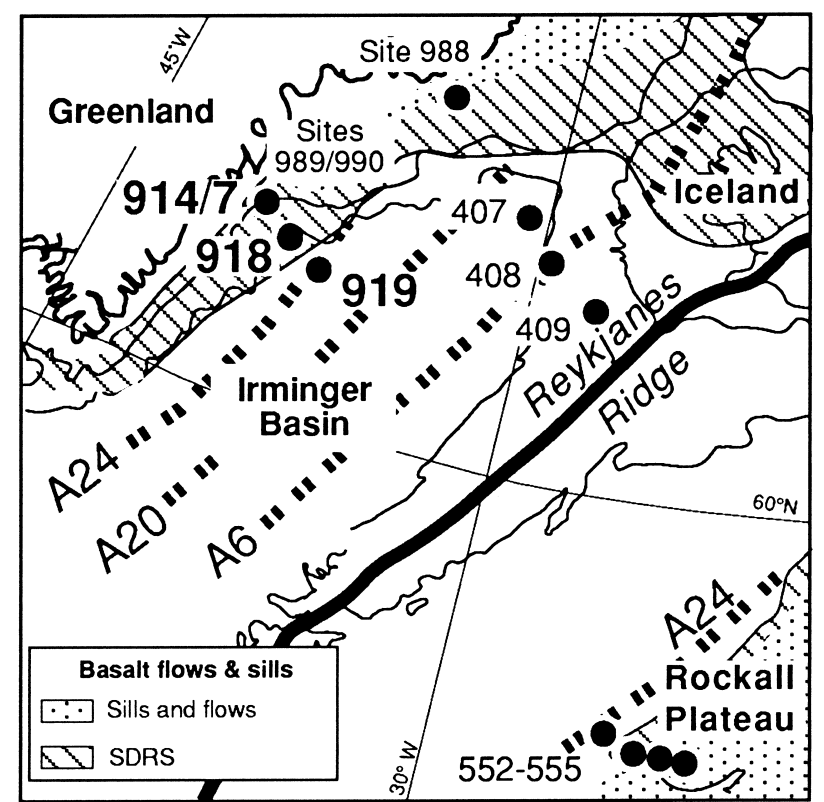

Figure 4. Map of the southeast Greenland Margin, showing the locations of the sites occupied during Leg 152 (and, for reference purposes, Leg 163). Modified from Larsen, Saunders, Clift, et al. (1994) and Duncan, Larsen, Allan, et al. (1996).

more detailed assessment is provided by Larsen and Saunders, this volume). Although drilling penetrated the entire section of SDRS at this locality, approximately $300 \mathrm{~m}$ of the lowest part of the succession is missing due to faulting (Fig. 5).

The Lower Series at Site 917 comprises basalts, olivine basalts, and picrites. The Middle Series comprises evolved basalts, dacites, and acidic pyroclastic deposits. At least one dacite, Unit 54, is a mixed assemblage, with basaltic clasts in a dacitic or rhyolitic matrix (Demant, this volume). The Middle and Upper Series are separated by a thin fluvial sandstone, which marks a significant change in lava composition from the evolved lavas and tuffs of the Middle Series, to more primitive olivine basalts and picrites of the Upper Series. The time interval represented by the fluvial sandstone is unknown; only $62 \mathrm{~cm}$ was recovered, and there is no change in the magnetic polarity of the lavas. Because of the marked change in composition between the Middle and Upper Series lavas (see below), the Lower and Middle Series have been grouped together into the "Continental Succession," and the Upper Series and the lavas from Sites 915 and 918 have been grouped into the "Oceanic Succession" (see Larsen and Saunders, this volume, for a full discussion). It should be noted, however, that the basalts from Site 915 do show evidence of contamination by continental crust (see below).

Drilling at Site 916, about $1 \mathrm{~km}$ southeast of Site 917, terminated in basaltic conglomerate, and will not be considered further in this account. Drilling at Site 915, about $4 \mathrm{~km}$ southeast of Site 917, was slightly more successful, penetrating two basalt units. Site 918 , located on the continental rise some $130 \mathrm{~km}$ from the Greenland coast, penetrated $121.6 \mathrm{~m}$ into basement, after drilling through nearly 1200 $\mathrm{m}$ of Holocene and Cenozoic sediments. Nineteen igneous units (18 flows and one sill) were recovered at this site.

A major objective of the subsequent Leg 163 was to extend this range of ages both to older sequences of lavas (Site 989, inboard of Site 917), and to intermediate ages to bridge the gap between Sites 915 and 917 (Site 990, which was essentially an extension of Site 915: Fig. 5). The drilling during Leg 163 was only partly successful and consequently we are left with a gap between the youngest lavas at Site 917 and the oldest lavas at Sites 915/990 (Duncan, Larsen, Al- 


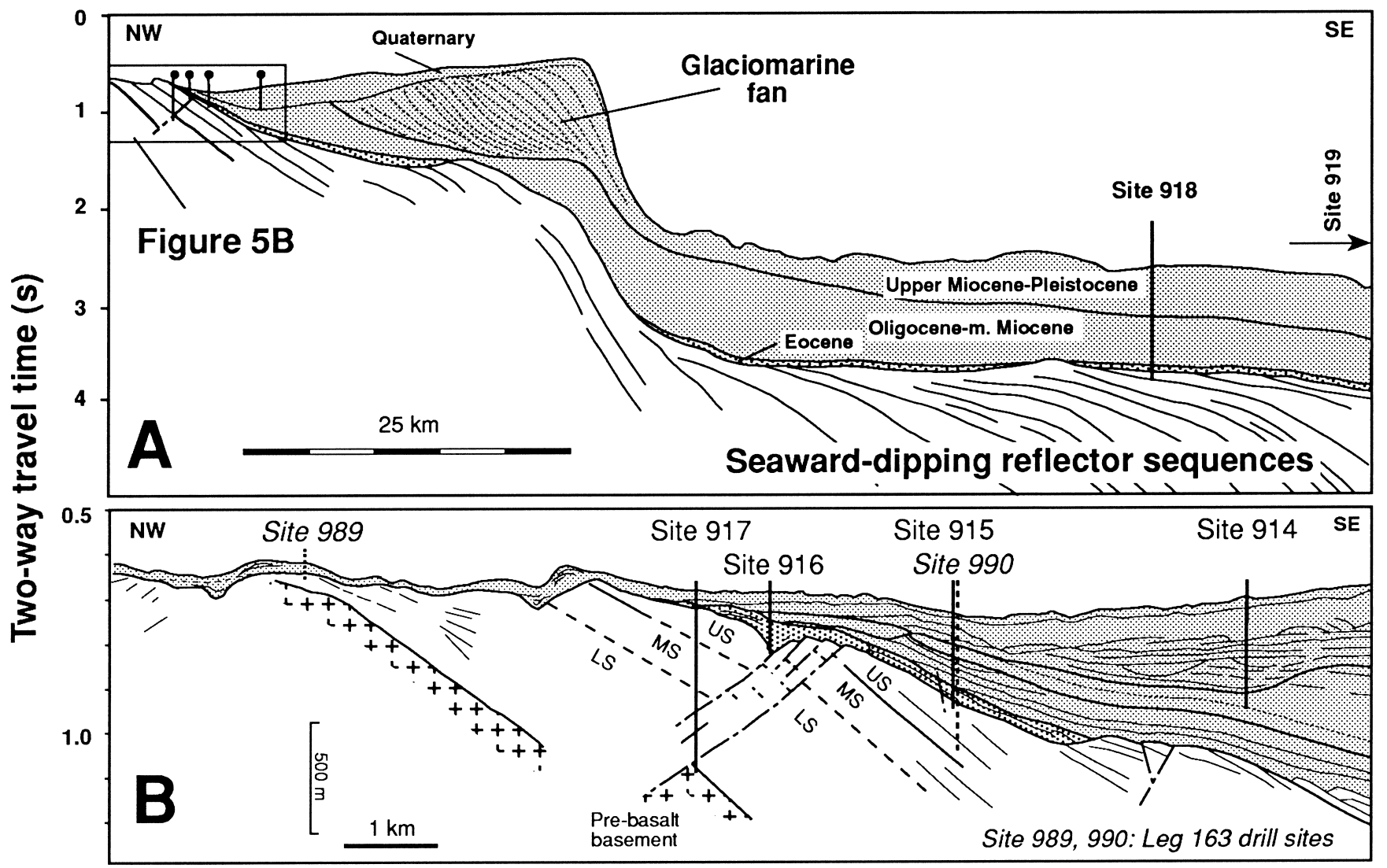

Figure 5. A. Northwest-southeast cross section of the southeast Greenland Margin along the Leg 152 drilling transect. B. Expanded portion of (A). Also included for reference are the sites drilled at $63^{\circ} \mathrm{N}$ during Leg 163. Modified from Larsen, Saunders, Clift, et al. (1994) and Duncan, Larsen, Allan, et al. (1996).

lan, et al., 1996). As reported in several papers in this volume, this is a frustratingly critical gap in the history of magmatism at this margin.

\section{VOLCANICLASTIC DEPOSITS}

Tephra deposits were recovered from most of the sites drilled during Leg 152. Paleogene volcaniclastic layers were found in Hole 918D below 1117.8 mbsf, and intercalated with the basaltic lavas. They also occur within and immediately overlying the lavas at Site 917. A few thin Paleogene volcaniclastic deposits were recovered from Holes 915A and 916A (Larsen, Saunders, Clift, et al., 1994; Werner et al., this volume). Well-preserved Neogene ash layers were found in the cores from Sites 918 and 919. Although there is an inherent uncertainty in relating such layers to the activity of a specific volcanic system, most of the Neogene ash layers are associated with volcanism in Iceland. The youngest events were particularly wellpreserved in the piston cores recovered from Holes 918A, 919A and 919B, and Lacasse et al. (this volume) have linked several fallout deposits recovered from Site 919 to specific Icelandic eruptions. Ashes recovered at Site 919, which was closest to Iceland, may be as much as $3 \mathrm{~cm}$ thick, whereas those from Site 918 are typically thinner and often dispersed, and without sharp contacts.

The Paleogene volcaniclastic deposits occur as highly altered ash layers, tuffs, lapillistones, breccias, and conglomerates (Werner et al., this volume). Six Eocene ash layers have been recognized in Hole 918D, and possibly correspond to the episode of abundant middle Eocene volcanism recognized in the North Atlantic region (Donn and Ninkovich, 1980). The source of this activity was probably the subaerial Iceland-Faeroes Ridge (Sigurdsson and Loebner, 1981). The lapillistones and tuffs found in the Middle Series at Site 917 have been mentioned previously. Some of these are primary pyroclastic fall and flow deposits, testifying to explosive, silicic volcanism.

The Neogene deposits are characterized by thin ash layers in the cores from Sites 918 and 919. The predominance of dense blocky shards in the mafic tephra deposits from Site 918 indicates that the tephra were derived from hydroclastic events, possibly associated with emergent submarine and subglacial/sublacustrine volcanoes (Werner et al., this volume). The composition of these tephra indicate that they were sourced in Iceland, rather than the Mid-Atlantic Ridge. Deposition of particles far from Iceland (up to $750 \mathrm{~km}$ ) may have been caused by turbidity currents originating on the Iceland shelf. A rhyolitic tephra layer of middle Miocene age probably represents a distal fallout deposit (Werner et al., this volume).

\section{AGE OF THE IGNEOUS BASEMENT}

Accurate crystallization ages of lavas associated with the SDRS are needed if we are to understand the relationship between rifting and magmatism. A more detailed assessment of age of the basement is presented by Larsen and Saunders (this volume); only a summary will be presented here. Prior to Leg 152, seafloor magnetic anomalies suggested that the bulk of the SDRS along the southeast Greenland Margin was emplaced during Chron C24r time (e.g., Larsen and Jakobsdóttir, 1988), implying very high rates of effusion and crustal accretion. Preliminary shipboard paleomagnetic studies were consistent with this suggestion (Larsen, Saunders, Clift, et al., 1994). Shore-based studies reported in this volume show, however, that the magmatism began substantially before $\mathrm{C} 24 \mathrm{r}$. Therefore, the duration of the activity is longer than previously suspected, and the discovery of older lavas, probably erupted during $\mathrm{C} 26 \mathrm{r}$ or possibly $\mathrm{C} 27 \mathrm{r}$ is of 
NW

SE

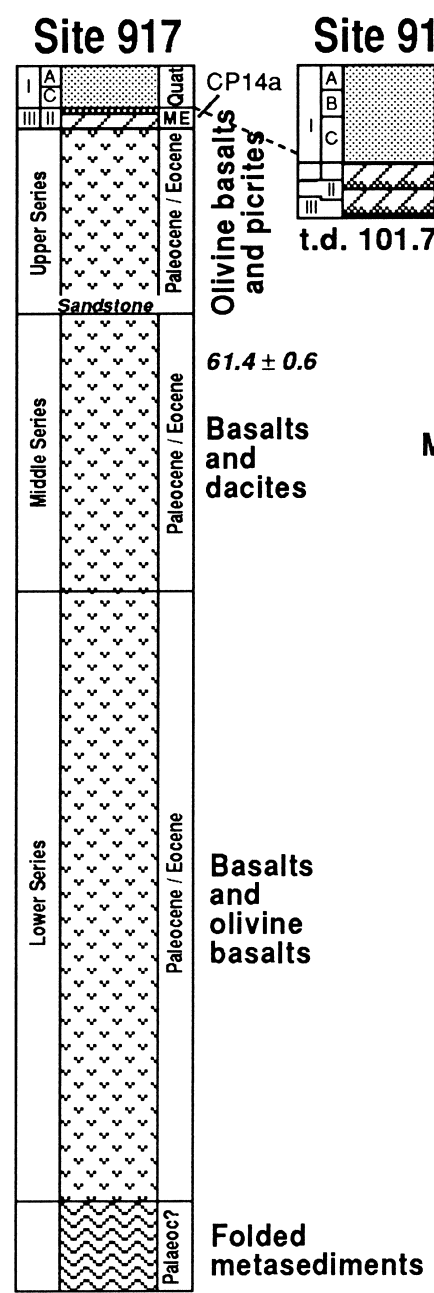

\section{5 \pm 0.5 Ar-Ar date, m.y.} CP14a Nannofossil zone

Marginal marine

to shelf

sediments

\section{Site 915}

Site 914

Site 918

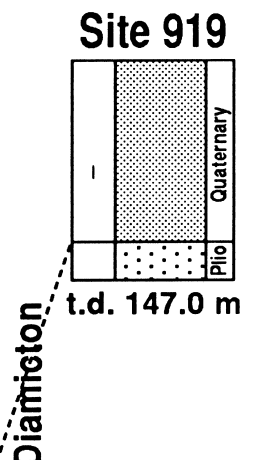

t.d. $874.9 \mathrm{~m}$

metasediments

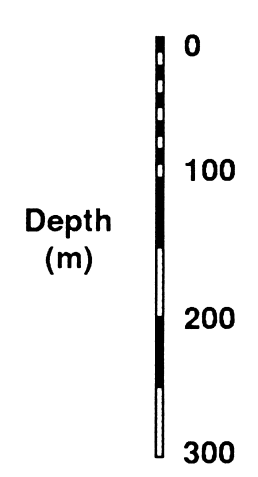

\section{Quaternary and Pliocene}

Deposits are predominantly glaciomarine sands, silts, and gravels, with or without dropstones.

Diamictons are common.

\section{Miocene}

Deposits include siltstones, often with a volcanogenic component, and nannofossil chalk.

\section{Oligocene}

Sediments include sand and silt turbidite.

\section{Eocene}

Sediments are predominantly volcanic silts, silts and nannofossil clays and chalk indicating shallow marine/transitional (lagoonal) environments.

$1,11, a, b$ Lithological units and subunits.

For the purpose of comparison, the seafloor at each site has been placed on the same datum line.

Figure 6. Summary lithologic logs for Leg 152 sites, based on Larsen, Saunders, Clift, et al. (1994). Additional information: Ar-Ar dates from Sinton and Duncan (this volume) and Werner et al. (this volume); nannofossil ages from Wei (this volume); palynological ages from Jolley (this volume). 
Table 1. Main characteristics of igneous lithologies drilled during Leg 152.

\begin{tabular}{|c|c|c|c|c|c|c|c|c|}
\hline Hole & $\begin{array}{c}\text { Subdivision } \\
\text { (cored thickness) }\end{array}$ & Units & $\begin{array}{l}\text { Emplacement } \\
\text { environment }\end{array}$ & Main lithologies & $\begin{array}{l}\text { Geochemical } \\
\text { characteristics }\end{array}$ & Magnetic polarity & ${ }^{40} \mathrm{Ar}^{-39} \mathrm{Ar}$ age & $\begin{array}{l}\text { Nannofossil and } \\
\text { palynoflora data }\end{array}$ \\
\hline \multirow[t]{2}{*}{$918 \mathrm{D}$} & $\begin{array}{l}\text { Sill-like unit } \\
\text { (3 to } 12 \mathrm{~m})\end{array}$ & $918-1$ & Intrusive & Basalt & $\begin{array}{c}\text { LREE enriched } \\
\text { High } \mathrm{Nb} / \mathrm{Zr}\end{array}$ & Reversed & $51.9 \pm 1.2$ m.y. & $\begin{array}{c}\mathrm{CP} 9 \mathrm{~b} / \mathrm{CP} 10 \\
\text { (ref 10) }\end{array}$ \\
\hline & $\begin{array}{l}\text { Lavas } \\
\quad(121.7 \mathrm{~m})\end{array}$ & $918-2$ to -19 & $\begin{array}{l}\text { Aa and pahoehoe } \\
\text { lavas; subaerial } \\
\text { to shallow } \\
\text { subaqueous }\end{array}$ & Basalt & $\begin{array}{l}\text { LREE depleted } \\
\text { Low }{ }^{87} \mathrm{Sr} /{ }^{86} \mathrm{Sr}\end{array}$ & Reversed & Not known & $\begin{array}{l}\text { CP9b (ref 10) } \\
\text { Ccl Zone (lower- } \\
\text { most CP10) } \\
\text { (ref 11) }\end{array}$ \\
\hline $915 \mathrm{~A}$ & $\begin{array}{l}\text { Lava } \\
\quad(20.4 \mathrm{~m})\end{array}$ & $915-1,2$ & Subaerial? & Plag-cpx-ol-basalt & LREE depleted & Reversed & Not known & $\mathrm{CP} 14 \mathrm{a}($ ref 10$)$ \\
\hline \multirow[t]{4}{*}{$917 \mathrm{~A}$} & $\begin{array}{l}\text { Upper Series } \\
(141.5 \mathrm{~m})\end{array}$ & $917-1$ to -33 & $\begin{array}{l}\text { Pahoehoe and aa } \\
\quad \text { lavas } \\
\text { Subaerial }\end{array}$ & $\begin{array}{l}\text { Aphyric olivine basalt, } \\
\text { olivine-phyric } \\
\text { basalt, picrite }\end{array}$ & $\begin{array}{l}\text { Variable degrees of } \\
\text { LREE depletion } \\
\text { and }{ }^{87} \mathrm{Sr} /{ }^{86} \mathrm{Sr} \text { ratios }\end{array}$ & Reversed & Not known & CP14a (ref 10) \\
\hline & $\begin{array}{l}\text { Thin sandstone } \\
\text { (67 cm } \\
\text { recovered })\end{array}$ & & Fluviatile & & & & & Not known \\
\hline & $\begin{array}{l}\text { Middle Series } \\
(193.4 \mathrm{~m})\end{array}$ & $917-34$ to -57 & $\begin{array}{l}\text { Mainly aa lavas } \\
\text { Pyroclastic rocks } \\
\text { Subaerial }\end{array}$ & $\begin{array}{l}\text { Aphyric basalt, } \\
\text { plagioclase-phyric } \\
\text { basalt, dacite, dacitic } \\
\text { tuff. Mixed lavas. }\end{array}$ & $\begin{array}{l}\text { Mainly LREE } \\
\text { enriched } \\
\mathrm{High} \mathrm{Ba} / \mathrm{Zr} \text {, and } \\
{ }^{87} \mathrm{Sr} /{ }^{86} \mathrm{Sr}\end{array}$ & $\begin{array}{l}\text { Reversed } \\
\quad(+1 \\
\text { cryptochron) }\end{array}$ & $\begin{array}{l}60.2-60.3 \text { m.y. }{ }^{9} \\
62.2 \pm 0.4 \text { m.y. }{ }^{8} \\
61.4 \pm 0.6 \text { m.y. }\end{array}$ & Not applicable \\
\hline & $\begin{array}{l}\text { Lower Series } \\
\quad(444.0 \mathrm{~m})\end{array}$ & $917-58$ to -92 & $\begin{array}{l}\text { Mainly subaerial aa } \\
\text { lavas, some } \\
\text { subaqueous } \\
\text { hyaloclastites }\end{array}$ & $\begin{array}{l}\text { Aphyric basalt, } \\
\text { aphyric ol-basalt, ol- } \\
\text { plag-phyric basalt, } \\
\text { ol-plag-cpx-phyric } \\
\text { basalt, ol-phyric } \\
\text { basalt, picrite }\end{array}$ & $\begin{array}{l}\text { Mainly LREE } \\
\text { enriched } \\
\text { Variable } \mathrm{Ba} / \mathrm{Zr} \text {, } \\
\mathrm{Nb} / \mathrm{Zr} \text {, and }{ }^{87} \mathrm{Sr} /{ }^{86} \mathrm{Sr}\end{array}$ & $\begin{array}{l}\text { Reversed }(+1 \\
\text { cryptochron) }\end{array}$ & Not known & Not applicable \\
\hline Ref & 1 & 1 & 1,2 & 1,3 & $1,4,5,6$ & 1,7 & 8,9 & $1,10,11$ \\
\hline
\end{tabular}

Notes: Holes are arranged in stratigraphic order. References: 1 = Larsen, Saunders, Clift, et al., 1994; 2 = Holmes (this volume); $3=$ Demant (this volume); 4 = Fitton et al. (Chap. 28 , this volume); $5=$ Fitton et al. (Chap. 29, this volume); $6=$ Fram et al. (this volume); $7=$ Vandamme and Ali (this volume); $8=$ Sinton and Duncan (this volume); $9=$ Werner et al. (this volume); $10=$ Wei (this volume); $11=$ Jolley (this volume). Abbreviations: LREE $=$ light-rare-earth element; ol $=$ olivine; $\mathrm{cpx}=\mathrm{clinopyroxene}$; plag $=$ plagioclase; ref $=$ reference.

major significance to our understanding of the development of this margin and the North Atlantic Igneous Province. (Note that throughout this paper we use the time scale of Cande and Kent, 1995, and Berggren et al., 1995.)

Three lines of evidence have been used to constrain the age of the southeast Greenland Margin magmatism: ${ }^{40} \mathrm{Ar} /{ }^{39} \mathrm{Ar}$ dating (Sinton and Duncan, this volume; Werner et al., this volume), magnetostratigraphy (Vandamme and Ali, this volume), and biostratigraphy (Jolley, this volume; Wei, this volume). We focus initially upon the ${ }^{40} \mathrm{Ar} /{ }^{39} \mathrm{Ar}$ data obtained by step-heating methods by Sinton and Duncan (this volume), and by laser fusion of feldspars (Werner et al., this volume).

The Lower and Middle Series lavas at Site 917 appear to have been erupted without a significant break, and during a reversed polarity event. The Middle Series contains sanidine-bearing tuffs which, with the dacites, offer the best opportunity for reliable dating of the succession. Sinton and Duncan (this volume) argue that the most reliable emplacement age is afforded by a dacite (152-917A-52R-1, $46-49 \mathrm{~cm})$, which gives an age of $61.4 \pm 0.6(2 \sigma)$ Ma. Feldspar separates from the tuffs give a range of ages $(60.3 \pm 0.2$ to $62.7 \pm 0.4$ : Sinton and Duncan, this volume, and Werner et al., this volume). The younger ages may in part be due to argon loss, which is not readily detected by laser fusion techniques, and the slightly older ages may be due to inherited argon (see discussion by Sinton and Duncan, this volume). An age of $60.4 \pm 0.7 \mathrm{Ma}$ for a plagioclase from a basalt from the Lower Series is within error of the $61.4 \pm 0.6 \mathrm{Ma}$ age of the Middle Series, and concordant with the $60.7 \pm 0.4$ Ma age for a dike exposed just landward of Site 917 (M. Storey, in Sinton and Duncan, this volume).

The $61.4 \pm 0.6 \mathrm{Ma}$ age for the Middle Series lavas, and their reversed magnetic polarity, are consistent with their emplacement during either the latest stage of C27r, or the earliest stage of C26r. However, stable, low inclination magnetic events within the Lower Series and near the top of the Middle Series (Vandamme and Ali, this volume) are interpreted as cryptochrons, suggesting that the succession was erupted during Chron C26r (no cryptochrons are known from C27r) (Larsen and Saunders, this volume).

Basalt samples taken from the Upper Series at Hole 917A failed to produce reliable plateaus or meaningful isochrons, due in part to the very low $\mathrm{K}_{2} \mathrm{O}$ content of these lavas. The Upper Series is separated from the Middle Series by a 62-cm-thick (recovered) sediment horizon, representing an eruption hiatus of unknown duration. Based on the absence of kaolinite in the sedimentary unit, Holmes (this volume) has argued that the hiatus lasted no more than 800,000 years. Lavas of the Upper Series, which exhibit both reversed polarity, may therefore have been erupted during C26r. It is important to stress that there is a marked change in magma composition between the Middle and Upper Series implying, but not requiring, a long hiatus.

The topmost igneous unit at Site 918 is a basaltic flow or sill that yielded a reliable age of $51.9 \pm 1.2 \mathrm{Ma}$. It has a reversed magnetic polarity, and the Ar-Ar date is consistent with emplacement during $\mathrm{C} 23 \mathrm{r}$, and with the normally magnetized host sediments being $\mathrm{C} 24 \mathrm{n}$. Sediment Sample 152-918D-93R-CC (1175.4 mbsf) contains nannoplankton assigned to $\mathrm{CP} 9 \mathrm{~b}$ (Wei, this volume) (53.6 to $52.9 \mathrm{Ma}$, C24n, according to the time scale of Berggren et al., 1995). The palynoflora suggest slightly younger ages, with an assemblage that correlates with lowermost CP10 or NP12 in the interval 1185.311188.37 mbsf (Core 152-918D-96R) (Jolley, this volume).

Ali and Vandamme (this volume) have proposed, on the basis of the nannoplankton, that the reversed and normal polarity events in the lower part of the sedimentary sequence at Hole 918D correspond with end C24r at 1185 mbsf; C24n.3n at 1185 to 1180 mbsf; C24n. $1 n$ at 1168-1166 mbsf; and C23n at 1158 to 1156 mbsf. Jolley (this volume) suggests, however, that the basal sediments belong to C23r, rather than C24r. The underlying basalts from the main SDRS at Site 918 were emplaced during a reversed polarity event, almost certainly C24r (Ali and Vandamme, this volume; Larsen et al., Chap. 39, this volume; Larsen and Saunders, this volume), but unfortunately there are no reliable ${ }^{40} \mathrm{Ar} /{ }^{39} \mathrm{Ar}$ dates from the basement successions at Site 918 or 915 (Sinton and Duncan, this volume). The presence of a magnetic anomaly identified by Larsen and Jakobsdóttir (1988) as C24r seaward of Site 918 means that the basalts at this site cannot be younger than $\mathrm{C} 24 \mathrm{r}$.

At the present time, therefore, the drilled SDRS span an age range from at least lower C26r (60-61 Ma) (with a remote chance of upper C27r, $\approx 61.5 \mathrm{Ma}$ ) in the Lower Series at Site 917, to as young as C24r at Site 918 (55.9-53.3 Ma). Larsen and Saunders (this volume) present a more detailed assessment of the eruption intervals. 


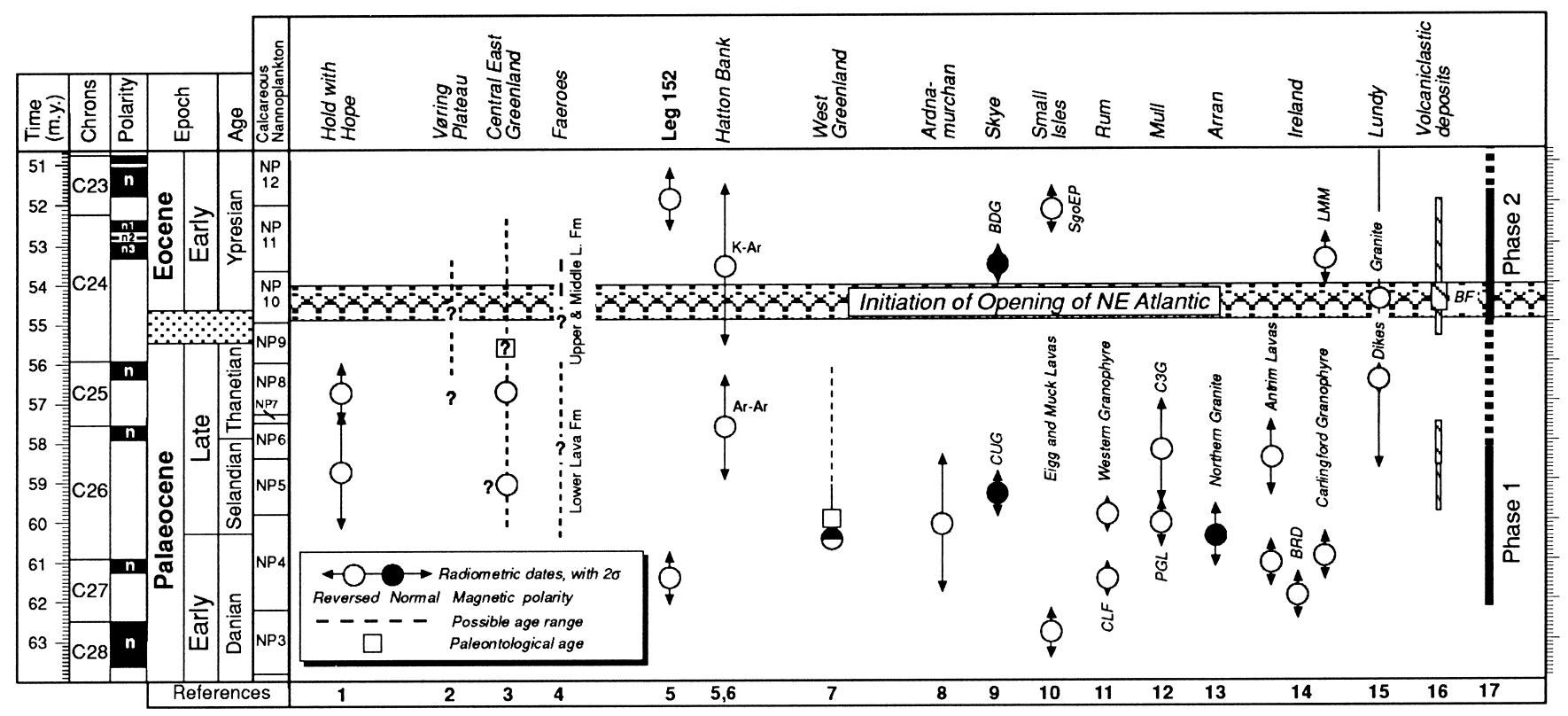

Figure 7. Time scale and event chart for the North Atlantic Igneous Province, modified from Saunders et al. (in press). Time scale from Berggren at al. (1995). References and comments: 1 = Upton et al. (1995); 2 = Schönharting and Abrahamsen (1989); 3 = Soper et al. (1976a, 1976b); Noble et al. (1988); Hansen et al. (1989); and Storey et al. (1996); 4 = Waagstein (1988); 5 = Sinton and Duncan (this volume) and Werner et al. (this volume); $6=$ Macintyre and Hamilton (1984); 7 = Parrott (1976); Parrott and Reynolds (1975); Clarke et al. (1983); Piasecki et al. (1992); and Storey et al. (1996); $9=$ Dickin (1981) $($ CUG = Coire Uaigneich granite; BDG = Beinn an Dubhaich granite); 10 = Dickin and Jones (1983); Dagley and Mussett (1986); and Pearson et al. (1996) (SgoEP = Sgurr of Eigg pitchstone); 11 = Mussett (1984) (CLF = Canna Lava Formation); $12=$ Mussett (1986) and Walsh et al. (1979) (PGL = Plateau Group Lavas; C3G = Centre 3 granite); 13 = Dickin et al. (1981) and Evans et al. (1973); 14 = Thompson (1986), Wallace et al. (1994), and Thompson et al. (1987) (BRD = Blind Rock Dyke; LMM = late Mourne Mountains granites); 15 = Hampton and Taylor (1983) and Mussett et al. (1976); $16=$ Knox and Morton (1983, 1988$) ; 17=$ see text. Age of initial opening of North Atlantic from Vogt and Avery (1974).

The discovery of 61-m.y.-old lavas in Hole 917A is of major significance. Prior to Leg 152, North Atlantic SDRS activity had been assumed to have begun in the latest Paleocene or early Eocene, although SDRS lavas had been recovered from only two other regions-Hatton Bank and the Vøring Plateau-and in neither region is the age control very good (Fig. 7). The basalts from the upper part of the sequence at Site 555 on the Hatton Bank margin (the most landward of the four sites drilled) are reversely magnetized and gave $\mathrm{K} / \mathrm{Ar}$ ages of $52.3 \pm 1.7$ and $54.5 \pm 2.0 \mathrm{Ma}$ (Macintyre and Hamilton, 1984), possibly corresponding to C24r. Basalt samples analyzed for ${ }^{40} \mathrm{Ar} /{ }^{39} \mathrm{Ar}$ by Sinton and Duncan (this volume) all show disturbed age spectra, although results for two lavas from Site 555 indicate eruption ages of $57.6 \pm 1.3$ and $57.1 \pm 5.6 \mathrm{Ma}$; these ages would correspond to C25r. Sediments belonging to nannofossil Zone NP9 (upper Paleocene), and thus younger than the Ar-Ar ages, underlie the basalts at this site (Backman, 1984).

The lavas recovered from the Lower Series at Site 642 on the Vøring Margin are all normally magnetized, whereas those of the Upper Series are reversely magnetized. The lavas have been tentatively assigned to C25n-C24r (Schönharting and Abrahamsen, 1989), but without radiometric age data this assignment must be considered as speculative. Various workers have suggested, on the basis of geochemical criteria, that the basalts belonging to the Upper Series at Site 642 correlate with the Lower Series basalts from the conjugate margin at Hold with Hope and Wollaston Forland (Viereck et al., 1988; Upton et al., 1995). Because the age of the northeast Greenland basalts is well constrained $\left(\mathrm{a}^{40} \mathrm{Ar} /{ }^{39} \mathrm{Ar}\right.$ date on a basal nephelinite from Hold with Hope gives an eruption age of 58.7 $\pm 1.4 \mathrm{Ma}$, and two dikes that post-date the lavas give ages of $56.7 \pm 0.7$ and $56.6 \pm 1.9$ Ma, respectively: Upton et al., 1995), an implication of this correlation, if correct, is that the Upper Series basalts from Site 642 are no younger than $\mathrm{C} 25 \mathrm{r}$.

The existence of pre-breakup lavas at Site 917 extends the spatial distribution of early Paleocene North Atlantic magmatism (Fig. 7).
That such magmatism occurred in eastern Canada, West Greenland, and the British Isles, is well documented (see for example, the reviews by Upton, 1988; Larsen et al., 1989; Larsen, Saunders, Clift, et al., 1994; Saunders et al., in press) but previously no lavas of this age have been documented from the East Greenland Margin. The basalts from central East Greenland have been assigned ages of approximately 57-53 Ma, on the basis of one Ar-Ar date (Hansen et al., 1989), K/Ar dates (Noble et al., 1988), and biostratigraphic evidence (e.g., Soper et al., 1976a, 1976b). The available published data indicate that entire sequence of the central East Greenland basalts, including the Lower Basalts, were erupted during a period of reversed polarity (e.g., Tarling, 1967; Soper et al., 1976b), although the sampling for paleomagnetic studies is incomplete. A marine dinoflagellate (Apectodinium homomorphum) is found in shales interbedded with hyaloclastites at the base of the Lower Basalts in the Kangerlussuaq region (Soper et al., 1976a, 1976b). Previous studies have suggested that the dinoflagellate has a range from mid-Thanetian to early Bartonian ( $\approx 56-40 \mathrm{Ma}$ on the time scale of Berggren et al., 1995), and its base corresponds to the base of nannoplankton zone NP9 (the so-called "Base Apectodinium Datum") (Powell, 1988), implying that the basalts were erupted during C24r (e.g., Berggren et al., 1985). However, this biostratigraphic control should be used with caution (D. Jolley, pers. comm., 1996). Several occurrences of Apectodinium spp. have been reported at stratigraphic levels below the Base Apectodinium Datum, and A. homomorphum occurs in strata of Danian age in the Maureen Formation of the central North Sea (Thomas, 1996). Given these uncertainties, it is likely that the basalts and picrites of the Lower Series at Kangerlussuaq are substantially older than the previous studies suggest. This has recently been confirmed by Storey et al. (1996) using ${ }^{40} \mathrm{Ar} /{ }^{39} \mathrm{Ar}$ ages to show that the oldest lavas in Central East Greenland may be as much as 60 m.y. old.

A picture is emerging therefore of widespread, Paleocene prebreakup magmatism, stretching from West Greenland, through East Greenland and to the British Isles, a distance of over $2000 \mathrm{~km}$ (Fig. 
3). Basalts from the lowest part of the Faeroes Plateau Lava Group may also have been erupted during the period C26r (Waagstein, 1988). Dates are required for the lavas recovered from the Vøring Plateau to verify if this Paleocene event also occurred to the north of the central East Greenland province. It is not known if these separate igneous provinces were once contiguous.

\section{ERUPTION ENVIRONMENT}

All three basement sites, 915, 917, and 918, provided important shipboard information about the environment of emplacement and subsequent alteration of the lavas (Larsen, Saunders, Clift, et al., 1994). This information has been subsequently reinforced by shorebased investigations (see Larsen and Saunders, this volume).

Both pahoehoe and aa lava flows are preserved in the Hole 917A core material. The lava thickness and type changes from the bottom to the top of the sequence, with thin pahoehoe flows becoming more common upsequence. This is particularly the case in the lavas of the Upper Series, where thin high-MgO and picritic lavas are common. The bulk of the lavas at Site 917 were emplaced in a subaerial environment, as demonstrated by the reddened and oxidized tops of many of the flows. Red soil horizons were also occasionally found. No pillow-like structures were recovered in the core, but brecciated and quenched bases to some flows, especially in the lower parts of the succession, suggest emplacement into shallow water or onto a wet land surface. Seismic profiles suggest that the top of the lava pile at Site 917 was removed by erosion. Lapillistones and tuffs are intercalated within the Middle Series basalts (Units 35 and 56). Werner et al. (this volume) have studied these units in detail, and divided each unit into a series of lithologically distinct pyroclastic deposits. Although some deposits appear to have been reworked by water, others are primary pyroclastic fallout or flow deposits. Unit $56 \mathrm{E}$ has a eutaxitic texture, indicating that it is a partially welded pyroclastic flow deposit (Larsen, Saunders, Clift, et al., 1994).

The lavas at Site 918 are predominantly aa in morphology, and were also erupted in a subaerial environment, despite now being located approximately $3 \mathrm{~km}$ below sea level. The presence of kaolinite in the topmost $17.5 \mathrm{~m}$ of weathered basalt indicates that subsequent alteration took place in fresh water, at pH levels of 6 or lower (Dixon, 1989; Holmes, this volume). The weathered basalt also contains gibbsite, suggesting that the climate was wet and warm (Holmes, this volume). The tops and bases of flows from lower in the sequence were altered to smectite and hematite, with chalcedony and calcite; this alteration may be produced in the marine or freshwater realm (Holmes, this volume).

\section{Comparisons with Other Volcanic Margins}

Basaltic units belonging to SDRS were cored at Sites 552 through 555 on the southwest Rockall Plateau-Hatton Bank, and at Sites 338, 342, and 643 on the Vøring Plateau.

A pillow-like structure was observed in the basaltic core recovered at Site 552. This evidence, together with the presence of overlying marine sediments, was taken by the Leg 81 shipboard party to indicate a subaqueous eruption environment (Roberts, Schnitker, et al., 1984). However, the short interval of cored basalts $(7.9 \mathrm{~m})$, the highly altered nature of the basalts, and the likelihood of unconformity between the sediments and the basalts, means that this interpretation should be used with caution. Coring of the SDRS at the adjacent Site 553 was much more successful (183.0 m cored), and the presence of scoriacious flow tops (several of which are oxidized) and inter-flow paleosols, is strongly supportive of a subaerial eruption environment. Note that Site 553 was located only 7 km north-northwest of Site 552.

Site 554 was the deepest water site drilled during Leg 81, near the western boundary of the SDRS on the Rockall Plateau. A total of 82.6 $\mathrm{m}$ of interbedded basalt lava flows, volcanogenic sandstones, and conglomerates was recovered, but recovery was poor (10\%), inhibiting interpretation. No pillow structures were found, but broken pillow fragments were found in breccia infills, implying submarine eruption. The evidence of erosion of the top of some flows, overlain by sandstones and basaltic clasts, implies a high-energy system, perhaps a littoral environment, shortly after emplacement of the lavas. This suggests that the eruptions were not in deep water.

Site 555, located in the saddle between the Edoras and Hatton Banks, was the most landward of the four sites drilled during Leg 81 . Basalt and interbedded sediments were cored for an interval of 292 $\mathrm{m}$. The basalts comprise both pillowed and massive flows; interbedded sediments are of shallow marine origin, indicating that the basaltic eruptions were again in relatively shallow water.

Sites 338 and 342 were drilled to basement on the Vøring Plateau, and both sites recovered small amounts of basalt. Site 343 was located at the foot of the western escarpment. From the limited amount of core, there is no clear evidence for environment of emplacement of the basaltic units; the shipboard party identified them as hypabyssal intrusions, but they may well be massive flows. The entire section recovered at Site 642, again on the main Vøring Plateau, was deposited in a terrestrial environment. In all, 136 lava flows were recognized in the core and, where evidence is available, appear to have been erupted subaerially.

\section{Implications}

The shallow-marine or subaerial eruption environments recorded in the lava stratigraphies from Sites 642 on the Vøring Plateau, Sites 553-555 on the Rockall Plateau-Hatton Bank, and Sites 915, 917, and 918 on the southeast Greenland Margin are of interest because they imply thermal support during rifting. When continental lithosphere is thinned by extension, the elevation of the surface changes to maintain isostatic equilibrium (e.g., McKenzie, 1978), normally subsiding during extension. For example, it has been calculated that the surface of continental crust will subside by more than $2 \mathrm{~km}$ at a $\beta$ factor of 5 (where $\beta=$ original thickness of crust or lithosphere/thickness of crust or lithosphere after extension), if the potential temperature of the underlying mantle is normal (i.e., approximately $1280^{\circ}-$ $1300^{\circ}$ : White and McKenzie, 1989). Thus, formation of oceanic crust, when $\beta$ factors approach infinity, is normally in deep marine conditions.

However, if the underlying asthenosphere is hotter than normal, four inter-related factors can reduce the amount of subsidence, or produce uplift. These four factors are (1) the large volumes of extra melt produced by melting of the hotter-than-ambient mantle, and which are emplaced into and onto the crust, causing it to thicken (e.g., McKenzie and Bickle, 1988); (2) the thermally induced buoyancy of the underlying asthenosphere; (3) the reduced density of the mantle after removal of melt; and, (4) close to the plume axis, the dynamic support of the ascending plume. White and McKenzie (1989) have estimated that if the underlying asthenosphere has a potential temperature of $1380^{\circ}$, the amount of subsidence of the crust is approximately $1 \mathrm{~km}$ at a $\beta$ factor of 2 , reducing slightly to $0.5 \mathrm{~km}$ at a $\beta$ factor of 5. At a potential temperature of $1480^{\circ}$, the surface of the crust rises by nearly $1 \mathrm{~km}$ at a $\beta$ factor of 5 . These calculations do not take into account any dynamically induced uplift above the plume axis. The southeast Greenland Margin was likely to have been too far removed from the plume axis for this to be an important factor; see Figure 3 and references given in figure caption.

The SDRS drilled on the Hatton Bank, Vøring Plateau, and at the shelf sites on the southeast Greenland Margin are underpinned by continental crust (e.g., Eldholm, Thiede, Taylor, et al., 1987; Morton and Taylor, 1987; Larsen, Saunders, Clift, et al., 1994; Larsen et al., Chap. 39, this volume). Furthermore, as we have already discussed, the lavas of the Lower and Middle Series from Site 917 are significantly older than the predicted ages of the main subcrop of the SDRS along the southeast Greenland Margin, and that they significantly 

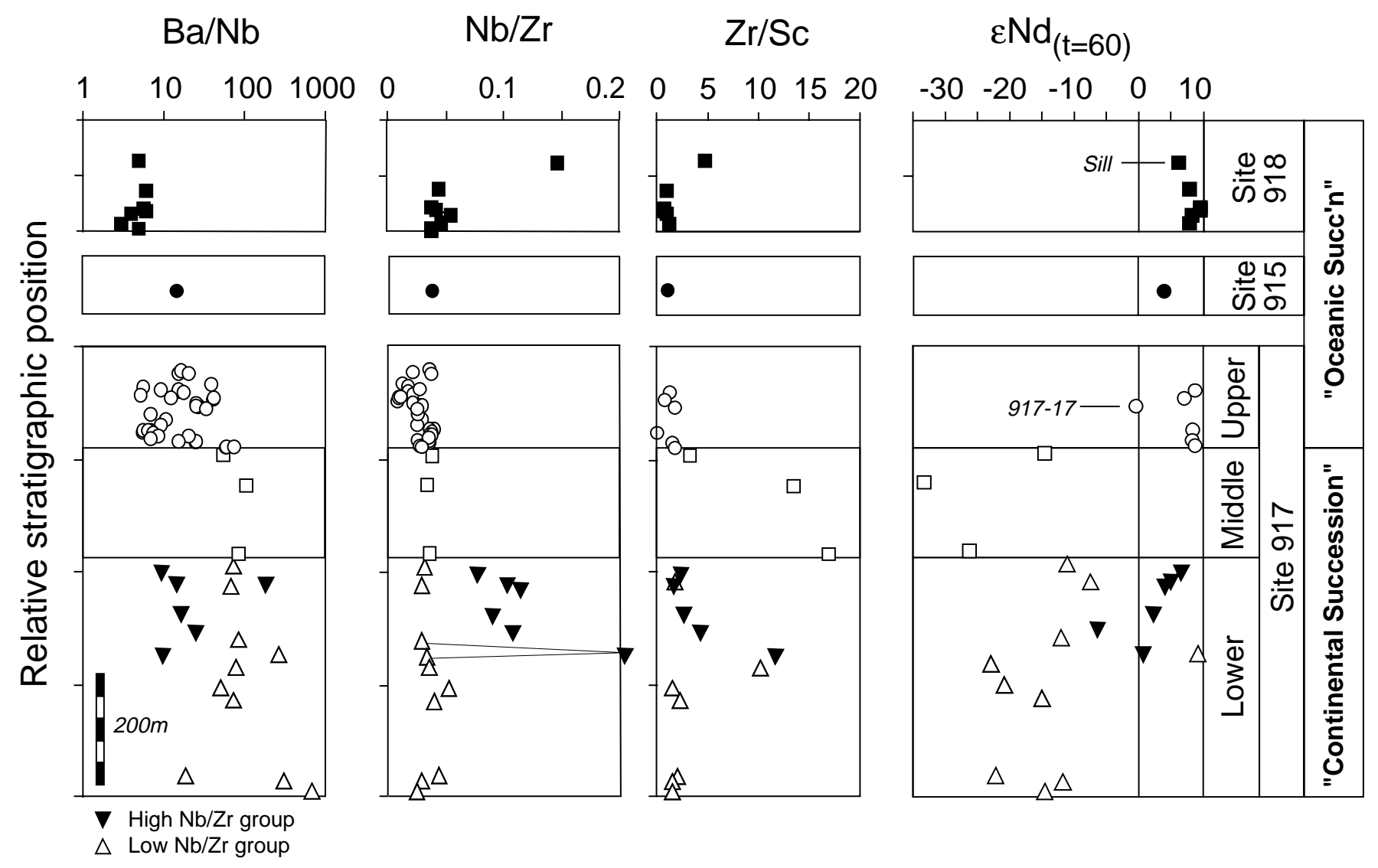

Figure 8. Downhole variation in composition of units (basalts and evolved rocks) recovered from Sites 917, 915, and 918. The samples are plotted in relative stratigraphic position, but within each site the samples are plotted as close as possible to absolute depth (except for Site 915). There is a marked change in Ba/Zr and $\varepsilon N d$ (and other parameters) between the Middle and Upper Series at Site 917, suggesting a declining contribution from continental crust upsequence. Note the low $\varepsilon N d$ of the high $\mathrm{MgO}$ basalt from Unit 917-17. Data from Fitton et al. (Chaps. 28 and 29, this volume).

predated the main episode of plate separation. Consequently, we cannot easily use these stratigraphies to compare subsidence rates with those observed in normal ocean crust or along nonvolcanic margins. Nevertheless, the basalts from Site 918 were all erupted subaerially, which does suggest that the asthenosphere was hotter than ambient at the time of rifting. This is consistent with the eruption of high-Mg basalts and picrites at Site 917 (see below) and, indeed, with the large volume of magmas that constitute the SDRS and underlying prisms of thickened igneous lower crust detected by seismic studies (e.g., White et al., 1987; Larsen and Jakobsdóttir, 1988; Mutter and Zehnder, 1988).

\section{COMPOSITION OF IGNEOUS ROCKS}

In the following sections we briefly review the main compositional characteristics of the lavas, in approximate order of emplacement. Detailed accounts can be found in Larsen, Saunders, Clift, et al. (1994), Larsen et al. (Chap. 27, this volume), Demant (this volume), Fitton et al. (Chaps. 28 and 29, this volume), Fitton et al. (1995), Fram et al. (this volume), and Thy et al. (this volume). Analyses of tephra are reported by Clift and Fitton (this volume), Lacasse et al. (this volume), and Werner et al. (this volume).

\section{Site 917}

The basalts and other igneous rocks recovered from Hole 917A suffered low grade, zeolite facies, metamorphism (Larsen, Saunders, Clift, et al., 1994). Peak temperatures may have reached $170^{\circ}$ during phyllosilicate formation, but were slightly lower, approximately $120^{\circ}-150^{\circ}$, during the formation of zeolites (Demant et al., this volume). Demant et al. (this volume) have also argued that the regular increase in cationic Na toward the top of the volcanic pile is due to the lava pile being open to seawater during the hydrothermal event.

Despite the alteration associated with the metamorphism, the succession at Site 917 records a striking change in magma composition that is related to the evolution of the rift margin. The majority of the lavas of the Lower and Middle Series are contaminated by continental crust, as shown by element ratios such as $\mathrm{Ba} / \mathrm{Nb}, \mathrm{Ba} / \mathrm{Zr}, \mathrm{La} / \mathrm{Th}$, $\mathrm{La} / \mathrm{Yb}$, and $\mathrm{Sr} / \mathrm{Zr}$, which, although being variable, are generally much higher than in the Upper Series lavas and in the lavas from Sites 915 and 918 (Fig. 8). The nature of the contaminants can be further constrained by $\mathrm{Sr}, \mathrm{Nd}$, and $\mathrm{Pb}$ isotopes, which clearly indicate that at least two contaminants are present: a low ${ }^{87} \mathrm{Sr} /{ }^{86} \mathrm{Sr}$, low $\varepsilon \mathrm{Nd}$ and high ${ }^{208} \mathrm{~Pb} /{ }^{204} \mathrm{~Pb}$ end member, and a high ${ }^{87} \mathrm{Sr} /{ }^{86} \mathrm{Sr}$, low $\varepsilon N d$ and low ${ }^{208} \mathrm{~Pb} /$ ${ }^{204} \mathrm{~Pb}$ end member (Figs. 9-12). These end members have been interpreted as being granulite and amphibolite facies continental crust, respectively (Fitton et al., Chap. 29, this volume). The contribution from these two end members decreases dramatically in the Upper Series, perhaps to zero (Fram et al., this volume), although Fitton et al. (Chap. 28, this volume) argue that several units (e.g., 917-17, which is a light-REE-enriched basalt, and with $\left.\varepsilon \mathrm{Nd}_{(\mathrm{t}=60)} \sim 0\right)$ retain evidence of small amounts of crustal contamination (Figs. 8, 10-12). Note, however, that several analyzed samples from the Upper Series have low ${ }^{87} \mathrm{Sr} /{ }^{86} \mathrm{Sr}$, and high $\varepsilon \mathrm{Nd}$, and form a tight cluster with basalts from Site 918 (Fig. 10). These samples, which also have low $\mathrm{La}_{\mathrm{n}} / \mathrm{Sm}_{\mathrm{n}}$, and $\mathrm{La} / \mathrm{Th}$, are thought to be uncontaminated by granulite or amphibolite facies crust. 


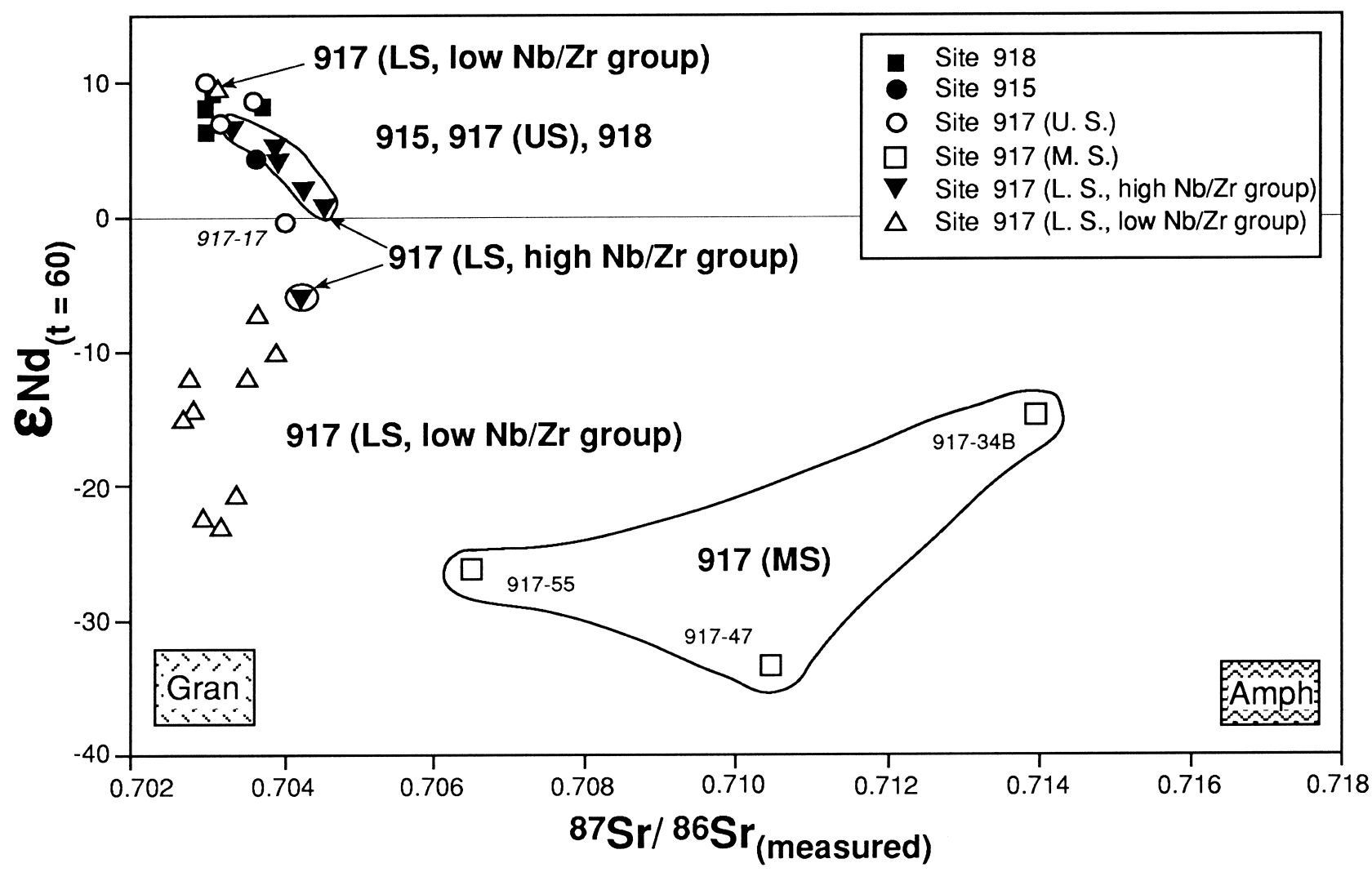

Figure $9 .{ }^{87} \mathrm{Sr} /{ }^{86} \mathrm{Sr}$ vs. $\varepsilon \mathrm{Nd}_{(\mathrm{t}=60 \mathrm{Ma})}$ for representative basalts and evolved rocks from the southeast Greenland Margin. Fields for Scottish Lewisian granulite and amphibolite from Dickin (1981). Data from Fitton et al. (Chap. 29, this volume).

Six units from near the top of the Lower Series have significantly higher $\mathrm{Nb} / \mathrm{Zr}$ than the other units in Hole 917A ( $>0.07$, where most of the lavas have $\mathrm{Nb} / \mathrm{Zr}<0.05$ ) (Figs. 8, 11). Such high $\mathrm{Nb} / \mathrm{Zr}$ ratios are also found in basalts from Iceland (e.g., Hémond et al., 1993; Hardarson and Fitton, 1994), from the Igtertiva Formation in the Scoresby Sund area (e.g., Larsen et al., 1989), and were recovered from Site 988 at $66^{\circ} \mathrm{N}$ during Leg 163 (J.G. Fitton, L.M. Larsen, and A.D. Saunders, unpubl. data). The high $\mathrm{Nb} / \mathrm{Zr}$ lavas have lower ${ }^{87} \mathrm{Sr} /$ ${ }^{86} \mathrm{Sr}$, higher $\varepsilon \mathrm{Nd}$, and much higher ${ }^{206} \mathrm{~Pb} /{ }^{204} \mathrm{~Pb}$ than most of the other Lower Series lavas (Figs. 9, 11, 12). The two groups of lavas from the Lower Series both show the effects of crustal contamination, best shown by the $\mathrm{Zr} / \mathrm{Nb}-\varepsilon \mathrm{Nd}$ plot (Fig. 11). At high $\varepsilon \mathrm{Nd}$, the low $\mathrm{Nb} / \mathrm{Zr}$ group intersects the N-MORB and the low-Nb/Zr end of the Iceland field.

The lavas recovered at Site 917 demonstrate a wide range of REE profiles. The basalts from the Lower Series show flat to light-REEenriched profiles $\left(\mathrm{La}_{\mathrm{n}} / \mathrm{Yb}_{\mathrm{n}}\right.$ ranging from 1.3 to 8.3), and the Middle Series basalts and dacites show strong light-REE enrichment $\left(\mathrm{La}_{\mathrm{n}} /\right.$ $\mathrm{Yb}_{\mathrm{n}}$ : 3.5-19), consistent with crustal contamination. Most of the basalts and picrites from the Upper Series are, however, depleted in light REE $\left(\mathrm{La}_{\mathrm{n}} / \mathrm{Sm}_{\mathrm{n}}\right.$ : 0.3-1.2) (Fig. 2), consistent with the marked change in magmatic processes recorded by other trace elements and radiogenic isotopes. Fram et al. (this volume) have recognized two partially overlapping groups within the Upper Series. Group 1 lavas, which predominate between 183.4 and 114 mbsf, are strongly lightREE-depleted $\left(\mathrm{La}_{\mathrm{n}} / \mathrm{Sm}_{\mathrm{n}}: 0.3-0.8\right)$, whereas the lavas of group 2 , which are found mainly in the upper part of the sequence, have slightly higher $\mathrm{La}_{\mathrm{n}} / \mathrm{Sm}_{\mathrm{n}}$ ratios (0.7 to 1.2) and higher abundances of Th, $\mathrm{Ba}$, and $\mathrm{Pb}$. Although some of this variation may be due to mantle melting processes or source composition, the negative correlation between $\mathrm{La}_{\mathrm{n}} / \mathrm{Sm}_{\mathrm{n}}$ and ${ }^{143} \mathrm{Nd} /{ }^{144} \mathrm{Nd}$, as mentioned above, suggests that at least part of the variation is due to crustal assimilation.

An important feature of the Upper Series lavas is the high frequency of high- $\mathrm{MgO}$ basaltic and picritic units (here we follow ship- board designation and use the term picrite to "denote a rock-type conspicuously rich in olivine phenocrysts (at least $15 \%$ by volume in hand specimen....). The term is used in a descriptive sense only and carries no implication of an unusually MgO-rich parental liquid." Accumulation of olivine phenocrysts must have occurred in all units defined as picrites by the Shipboard Scientific Party (Larsen, Saunders, Clift, et al., 1994). Some aphyric or only sparsely olivine-phyric units are, however, also magnesian (for example, Unit 917-16 is aphyric, contains $18 \mathrm{wt} \% \mathrm{MgO}$, and has an $\mathrm{Mg} \#(100 \mathrm{Mg} /[\mathrm{Mg}+\mathrm{Fe}])$ of 77$)$. High Fo contents (up $\mathrm{Fo}_{92}$ : Demant, this volume) and skeletal morphology of olivine phenocrysts also indicate that the magmas were near primary in composition. Thy et al.(this volume) estimate that the magma that gave rise to Unit 917-13 had a primary melt composition of $\sim 18 \mathrm{wt} \% \mathrm{MgO}, \sim 11 \mathrm{wt} \% \mathrm{FeO}_{\mathrm{T}}, \sim 1 \mathrm{wt} \% \mathrm{TiO}_{2}$, and a 1-atmosphere liquidus temperature of $\sim 1380^{\circ} \mathrm{C}$.

High-MgO basalts were also recovered from the Lower Series lavas (e.g., Units 917-61B, -62, -73A, and -88), and form four distinct peaks in the succession $(420,550,775$, and $810 \mathrm{mbsf})$. These high$\mathrm{MgO}$ and high-Ni lava flows are separated by more evolved basalts. This broad cyclical pattern contrasts with the flow-by-flow oscillations observed in the Upper Series, and suggests that the lava flows were fed by large, long-lived magma chambers (Larsen, Saunders, Clift, et al., 1994; Fitton et al., 1995). None of the magnesian lavas from the Lower Series is as primitive as the most primitive lava from the Upper Series, but Thy et al. (this volume) estimated that the basalt from Unit 84 had a primary melt composition of $\sim 15 \mathrm{wt} \% \mathrm{MgO}$, $\sim 10 \% \mathrm{FeO}_{\mathrm{T}}, \sim 0.9 \mathrm{wt} \% \mathrm{TiO}_{2}$, and a 1-atm liquidus temperature of $1337^{\circ}$.

\section{Sites 915 and 918}

One basalt flow unit was recovered at Site 915, and 18 flow units at Site 918 . All of the analyzed Site 918 flows show the effects of low-temperature alteration (Larsen, Saunders, Clift, et al., 1994), but 


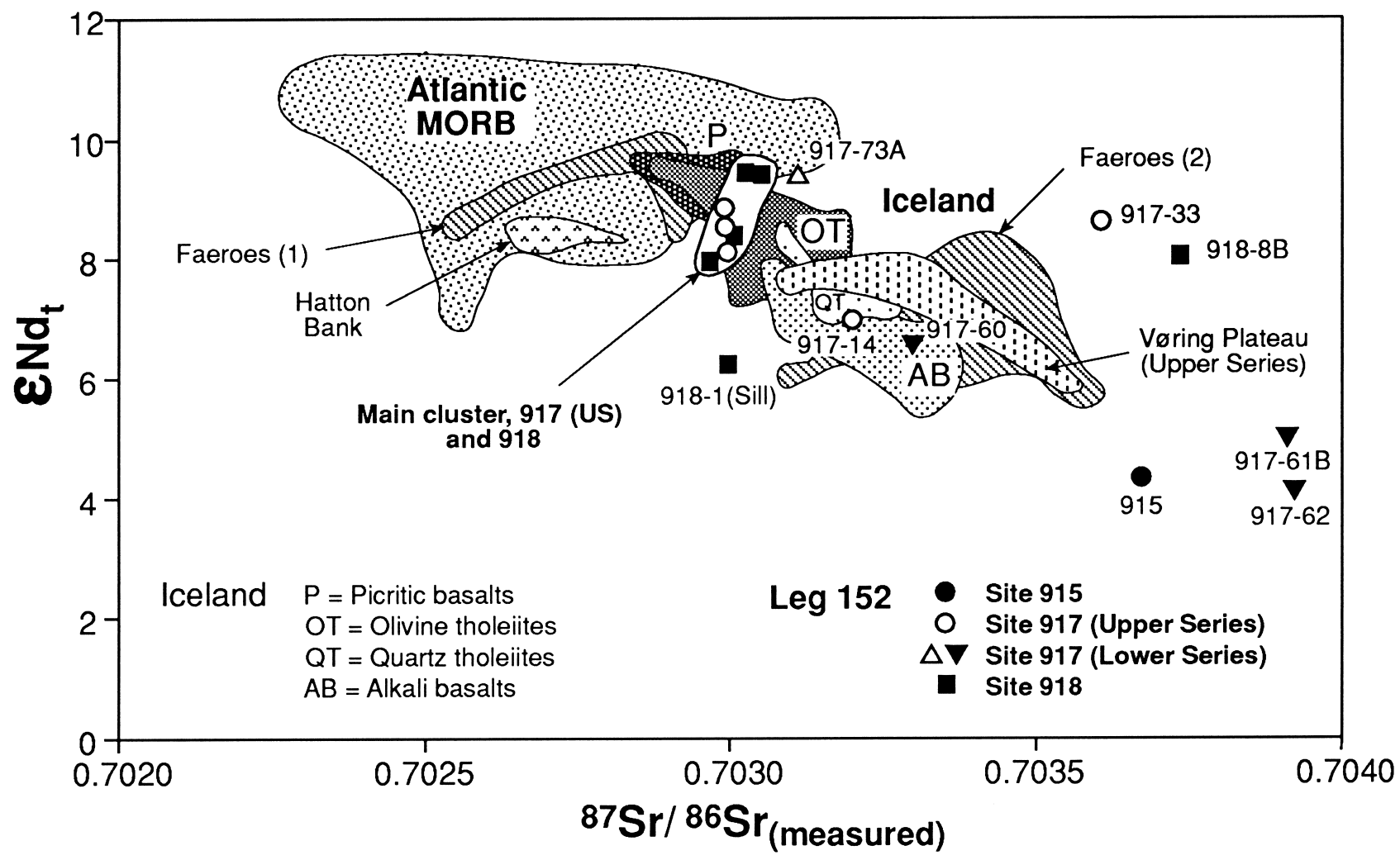

Figure 10. $\varepsilon \mathrm{Nd}(\mathrm{t}=60 \mathrm{Ma}){ }^{\mathrm{vs} .}{ }^{87} \mathrm{Sr}^{86} \mathrm{Sr}_{(\mathrm{t}=60 \mathrm{Ma} \text { or measured })}$ for basalts and related rocks from the North Atlantic Province. Expanded part of Figure 9, showing the variation in Icelandic basalts and picrites, and basalts from Site 917 (Upper Series and some Lower Series), Site 915, and Site 918. Also included are data for the Upper Series of Site 642 on the Vøring Plateau; light-REE-enriched basalts from the Faeroe Plateau Lava Group (Faeroes 2); and light-REE-depleted basalts from the Faeroe Plateau Lava Group (Faeroes 1) and Hatton Bank. Data sources: Leg 152 rocks = Fitton et al. (Chap. 29, this volume); Atlantic N-MORB = Ito et al. (1987); Faeroes = Gariépy et al. (1983); Iceland = Hémond et al. (1993) and references therein; Vøring Plateau = Taylor and Morton (1989); Hatton Bank = Macintyre and Hamilton (1984). Samples have been age corrected to their approximate age of emplacement where data allow; otherwise present-day Sr isotope values are plotted. The shift due to age correction is small compared to the overall range of values.

unlike the basalts from Site 917, the abundances of the mobile elements $\mathrm{Rb}, \mathrm{K}$, and Ba remain consistently low (Fig. 13). Note, however, that the basalt from Site 915 shows increased concentrations of these elements. Unit 918-1, which was emplaced into sediments, appears to be a sill.

Apart from Unit 918-1, all of the analyzed basalts recovered from Site 918 are light REE depleted, with $\mathrm{La}_{\mathrm{n}} / \mathrm{Sm}_{\mathrm{n}}<0.73$, and with relatively high heavy-REE and Sc contents $\left(\mathrm{Sm}_{\mathrm{n}} / \mathrm{Lu}_{\mathrm{n}}<1\right.$, and $\mathrm{Zr} / \mathrm{Sc} 0.7-$ 1.2) (Figs. 2, 8, 14). There is a significant decrease in $\mathrm{Sm}_{n} / \mathrm{Lu}_{n}$ throughout the Upper Series lavas at Site 917; this ratio remains low in the basalts from Site 915 and 918, apart from Unit 918-1 (Fig. 14). Fram et al. (this volume) and Fitton et al. (Chap. 28, this volume) attribute the decreasing $\mathrm{Sm}_{\mathrm{n}} / \mathrm{Lu}_{\mathrm{n}}, \mathrm{Zr} / \mathrm{Sc}$, and Hf/Lu to progressive shallowing of melt segregation as the rift margin developed (see below).

A subset of basalts from Sites 917 and 918 plot in a small cluster that overlaps the field of high- $\varepsilon \mathrm{Nd}_{(\mathrm{t}=60)}$ and low- ${ }^{87} \mathrm{Sr} /{ }^{86} \mathrm{Sr}$ Icelandic basalts. There is also a slight overlap with North Atlantic N-MORB (Fig. 10). Some samples from Site 918 (e.g., Unit 918-8B) have high ${ }^{87} \mathrm{Sr} /{ }^{86} \mathrm{Sr}$ values, indicative of low-temperature alteration by seawater, despite the samples being leached prior to analysis. The lavas from Site 918 are indistinguishable from N-MORB and Icelandic basalts on the ${ }^{208} \mathrm{~Pb} /{ }^{204} \mathrm{~Pb}-{ }^{206} \mathrm{~Pb} /{ }^{204} \mathrm{~Pb}$ isotope diagram (Fitton et al., Chap. 29, this volume; Fig. 12). This, and the evidence from trace elements and the $\varepsilon N d-{ }^{87} \mathrm{Sr} /{ }^{86} \mathrm{Sr}$ diagram, indicates that crustal contamination of these lavas was not significant.

The basalt from Site 915 plots below and to the right of the main Icelandic fields on the $\varepsilon N d-{ }^{87} \mathrm{Sr} /{ }^{86} \mathrm{Sr}$ plot, and to the left of the main Iceland-N-MORB arrays on the ${ }^{208} \mathrm{~Pb} /{ }^{204} \mathrm{~Pb}-{ }^{206} \mathrm{~Pb} /{ }^{204} \mathrm{~Pb}$ isotope diagram. These characteristics are consistent with the elevated abundances of $\mathrm{Rb}, \mathrm{Ba}$, and $\mathrm{K}$ in the Site 915 basalt, and are indicative of contamination, either during ascent of the magma through the crust, or by circulating fluids in the lava pile.

\section{Summary of Main Temporal Changes in Lava Composition}

The analyzed core material records dramatic temporal changes in magma chemistry, which encompass most of the variation seen in the NAIP as a whole. Secondary alteration (for example, the development of zeolites in much of the core from Hole 917A) cannot alone account for the majority of variation. The significant changes that occur, include the following:

1. The occurrence of high $\mathrm{Nb} / \mathrm{Zr}$ basalts and high-MgO basalts toward the top of the Lower Series at Site 917. These basalts resemble those found in the Tertiary sequences on Iceland. The bulk of the basalts recovered from Sites 917,915 , and 918 have low $\mathrm{Nb} / \mathrm{Zr}$.

2. Eruption of high-SiO $\mathrm{S}_{2}$ lavas (dacite flows and pyroclastic deposits) and evolved basalts in the Middle Series. These lavas probably represent contamination of basaltic magmas by continental crust (see below).

3. A dramatic decrease in $\mathrm{Ba} / \mathrm{Zr}, \mathrm{Ba} / \mathrm{Nb},{ }^{87} \mathrm{Sr} /{ }^{86} \mathrm{Sr}, \mathrm{La} / \mathrm{Sm}$, and $\mathrm{La} / \mathrm{Yb}$, and increase in $\varepsilon \mathrm{Nd}$, between the Middle and Upper Series at Site 917 . This has been interpreted as a reduction of the amount of crustal contamination in the magmas.

4. Eruption of basaltic and picritic magmas in the Upper Series at Site 917, with large variation in $\mathrm{MgO}$ content. The majority of these lavas are light REE depleted, with isotope ratios similar to those found in uncontaminated N-MORB and Icelandic ba- 


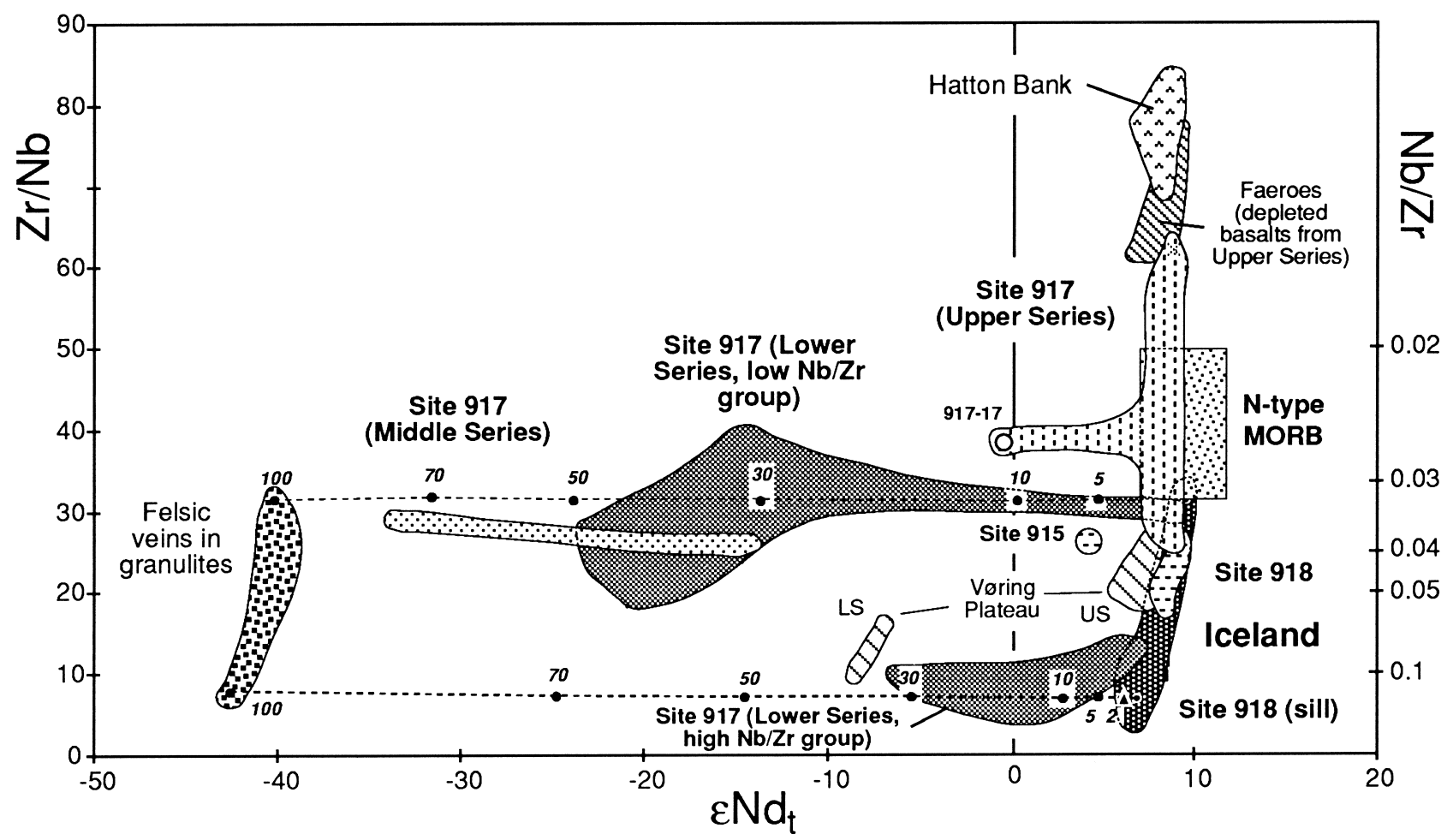

Figure 11. Zr/Nb vs. $\varepsilon N d$ in lavas from the North Atlantic Province. Note the subhorizontal dispersion indicative of mixing between a high $\varepsilon N d$ sublithospheric source, and a low $\varepsilon N d$ contaminant. Two bulk assimilation lines are shown, between Archean felsic veins and two end members of the Iceland array (figures give percentage of contaminant). Data sources as for Figure 10. Field for Atlantic N-MORB assembled from data in Ito et al. (1987) and A.D. Saunders and J.G. Fitton (unpubl. data).

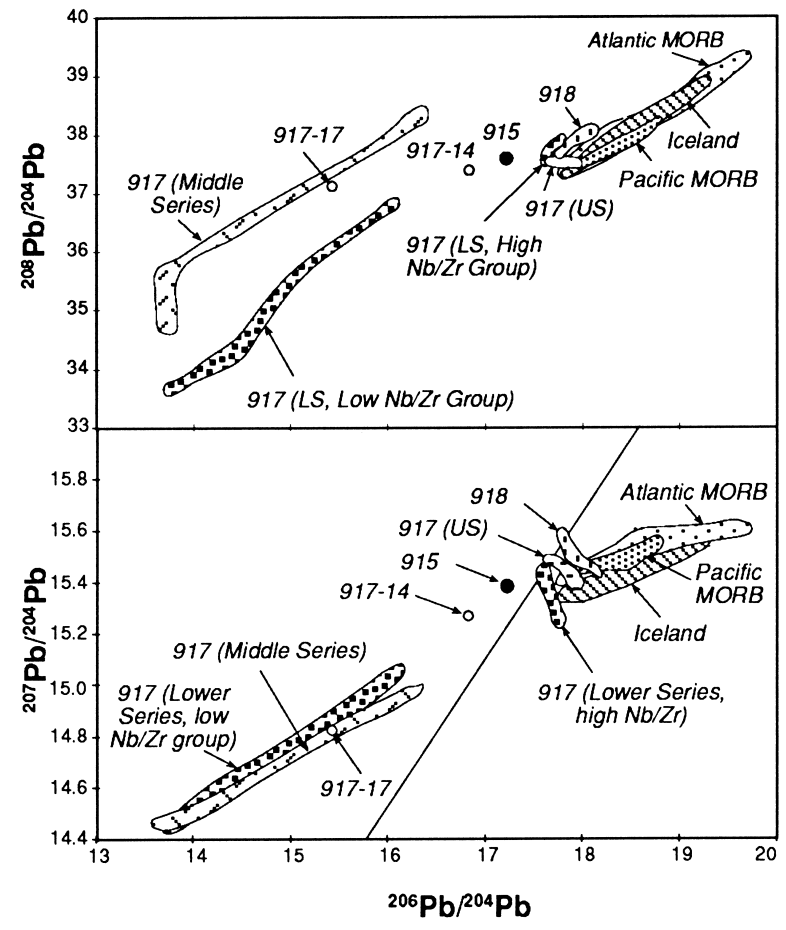

Figure 12. ${ }^{207} \mathrm{~Pb} /{ }^{204} \mathrm{~Pb}$ and ${ }^{208} \mathrm{~Pb} /{ }^{204} \mathrm{~Pb}$ vs. ${ }^{206} \mathrm{~Pb} /{ }^{204} \mathrm{~Pb}$ for Leg 152 lavas, compared with basalts from Iceland and mid-ocean ridges. The trend to low ${ }^{206} \mathrm{~Pb} /{ }^{204} \mathrm{~Pb}$ by the lavas of the Middle Series, and most of the lavas of the Lower Series, indicates substantial contamination of magmas by continental crust. Data sources: Leg $152=$ Fitton et al. (Chap. 29, this volume); Iceland $=$ Furman et al. (1991; 1995), Sun and Jahn (1975), Cohen and O'Nions (1982), Elliott et al. (1991). Pacific and Atlantic MORB = Ito et al. (1987).

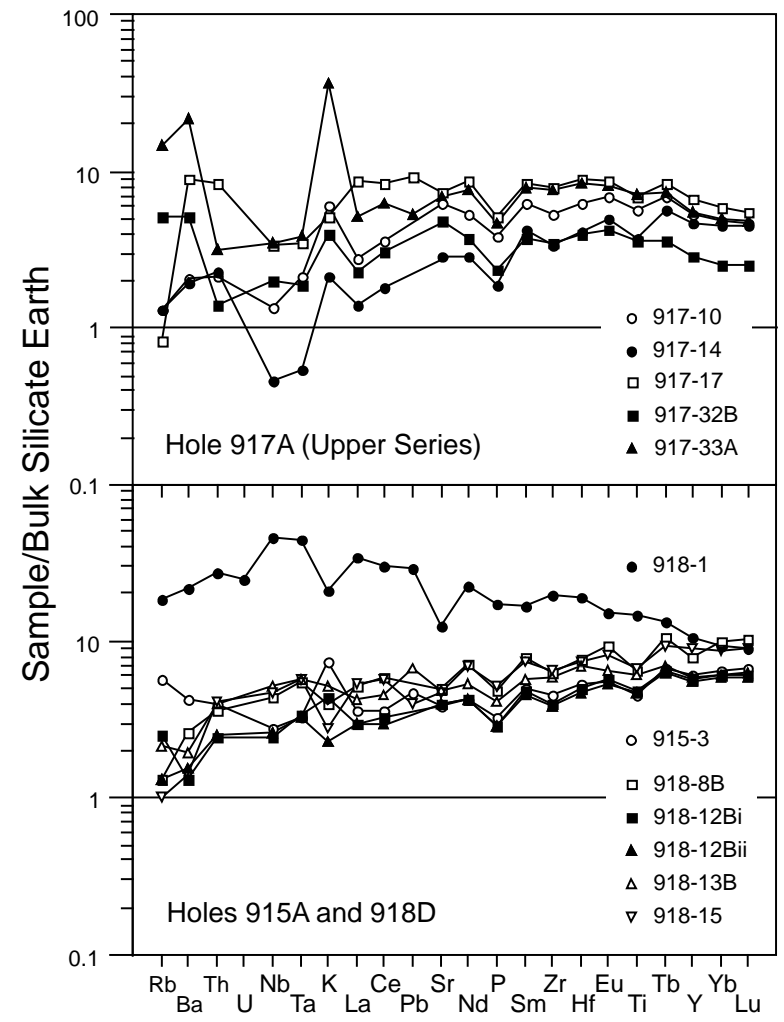

Figure 13. Multi-element plot, normalized to bulk silicate earth (McDonough and Sun, 1995), for basalts recovered from Sites 915 and 918, southeast Greenland Margin. After Fitton et al. (Chap. 28, this volume). 


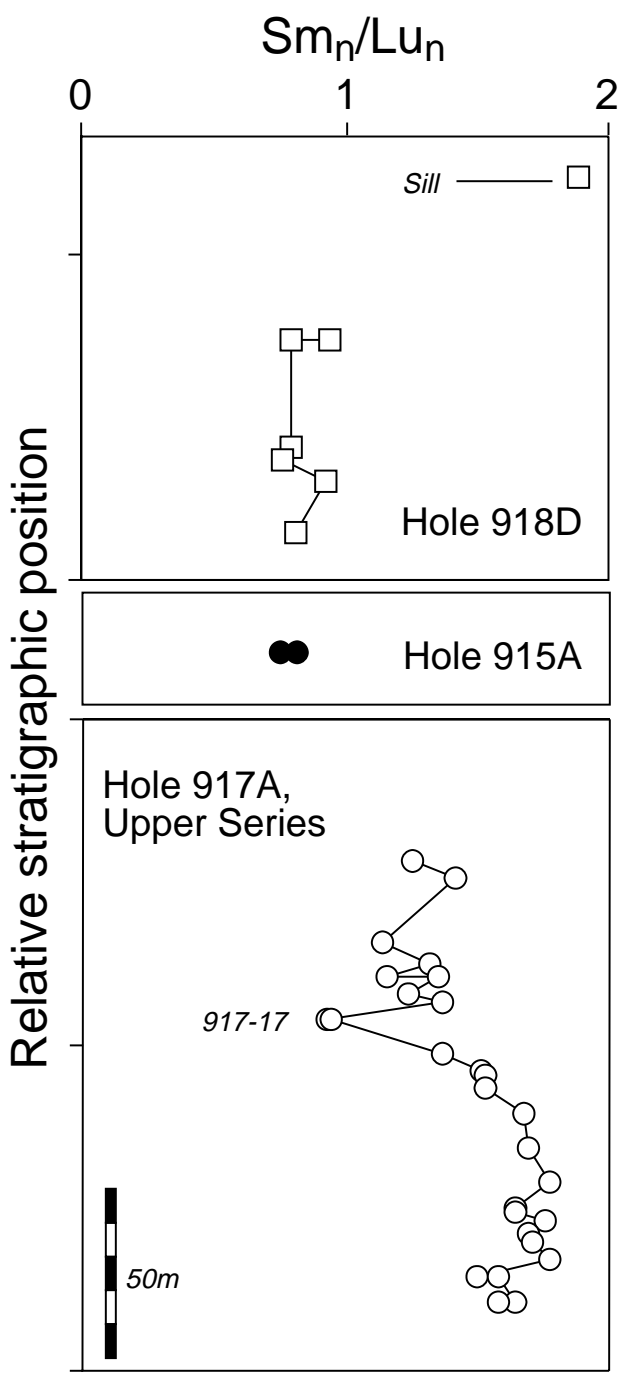

Figure 14. Downhole variation in chondrite-normalized $\mathrm{Sm} / \mathrm{Lu}$ at Sites 917 (Upper Series), 915, and 918. Cores are restored to their relative stratigraphic positions. Note the steady upcore decrease in $\mathrm{Sm} / \mathrm{Lu}$ in the Upper Series lavas from Site 917, implying either decreasing depth of melt segregation, and/or decreasing effects of crustal contamination. Sample 917-17 has low $\varepsilon \mathrm{Nd}$ and low ${ }^{206} \mathrm{~Pb} /{ }^{204} \mathrm{~Pb}$, implying that this unit was contaminated. Data from Fram et al. (this volume) and Fitton et al. (Chap. 28, this volume).

salts. Some of the basalts from the Upper Series at Site 917 do, however, show signs of being contaminated (e.g., Unit 91717), having $\mathrm{La}_{\mathrm{n}} / \mathrm{Yb}_{\mathrm{n}}>1$, high ${ }^{87} \mathrm{Sr} /{ }^{86} \mathrm{Sr}$, and low $\varepsilon \mathrm{Nd}$.

5. The eruption of light-REE-depleted basalts continued throughout the formation of the SDRS sampled at Sites 915 and 918 (and, also, Sites 989 and 990). The basalt from Site 915 shows element and isotope evidence for modest contamination by continental crust, but the Site 918 basalts are apparently uncontaminated. The MgO contents of the Site 915 and 918 basalts show much less variation than those recovered from Site 917, consistent with development of magma chambers (Fitton et al., 1995).

6. $\mathrm{Sm} / \mathrm{Lu}, \mathrm{Hf} / \mathrm{Lu}$, and $\mathrm{Zr} / \mathrm{Sc}$ consistently decrease throughout the Upper Series at Site 917, and the lavas erupted at Sites 915 and 918 maintain low values of these ratios, consistent with a shallowing of the depth of melt segregation and/or declining amounts of crustal assimilation. The absence of any clear correlation between $\mathrm{Sm} / \mathrm{Lu}$ and $\varepsilon \mathrm{Nd}$ implies that crustal assimilation is not the main cause of this uphole variation.
7. The youngest igneous unit at Site 918 was the sill (Unit 9181), which has high $\mathrm{La} / \mathrm{Yb}$ and $\mathrm{Nb} / \mathrm{Zr}$, and resembles some basalts erupted in Iceland.

\section{DISCUSSION}

Large igneous provinces (LIPs) include continental flood basalts, oceanic plateaus, and the large volumes of magma emplaced along volcanic rifted margins (e.g., Coffin and Eldholm, 1993). Although many workers attribute the large volumes of magma to decompression of hotter-than-ambient mantle $\left(\approx 1300^{\circ} \mathrm{C}\right.$ : McKenzie and Bickle, 1988 ), there is no consensus about how such hot mantle is generated, nor indeed how it is transferred into regions of magma generation. Understanding these problems by studying the composition of erupted magmas is fraught with uncertainty, not least because many magmas have interacted (by cooling and contamination) with lithosphere through which they have ascended. This problem is exacerbated in continental flood basalt sequences, where there is often strong evidence for contamination of magma either by crust (e.g., Deccan: Mahoney, 1988; Hebrides: Dickin, 1988), by subcontinental lithospheric mantle (e.g., Paraná: Hawkesworth et al., 1988), or by both (e.g., Arndt and Christensen, 1992; Saunders et al., 1992). The lithosphere also controls the depth at which melt segregation occurs, by truncating the melt column (e.g., Fram and Lesher, 1993; Fram et al., this volume). The plume mantle, on the other hand, provides the bulk of both the thermal energy for melting and the material that is eventually melted (e.g., McKenzie and Bickle, 1988).

A major goal of Leg 152 was to evaluate the role of the ancestral Iceland thermal anomaly in the genesis of the southeast Greenland SDRS in particular, and of the NAIP is general. From the foregoing it is apparent that before we can achieve this goal, it is necessary to account for the effects of crustal contamination and the lithospheric "lid." Only then is it possible to identify the nature-thermal and compositional —of the sublithospheric mantle. Furthermore, it is necessary to fingerprint the plume mantle, ideally using isotope or trace elemental criteria, but also using less direct information such as the temperature of the sublithospheric mantle.

\section{Crustal Contamination}

There is a marked temporal variation in the extent and nature of crustal contamination of the southeast Greenland lavas. The basalts from the Lower and Middle Series at Site 917 show clear evidence for contamination, culminating in the formation of dacites in the Middle Series. Contamination decreases rapidly in the basalts and picrites of the Site 917 Upper Series, with several units showing no evidence for any contamination. The basalt from Site 915 appears to be only slightly contaminated, and those from Site 918 are uncontaminated. This marked division between contaminated and uncontaminated magmas was also reported in the lavas from Site 642 on the Vøring Plateau (e.g., Viereck et al., 1988), where cordierite-bearing dacites predominate in the Lower Series, but relatively uncontaminated basalts make up the bulk of the Upper Series.

Larsen, Saunders, Clift, et al. (1994), Fitton et al. (1995), and Larsen et al. (this volume) relate the temporal changes in magma composition to the evolving nature of the rifted margin. With the new Ar-Ar ages reported in this volume (Sinton and Duncan, this volume; Werner et al., this volume), and the knowledge that the Lower and Middle Series are much older than hitherto thought, it is now possible to refine these models slightly. Both the Middle and Lower Series belong to Chron C26r or C27r, and not C24r as estimated by Larsen, Saunders, Clift, et al. (1994). It is therefore likely that both series were erupted before the main phase of rifting, and can be considered as continental flood basalts. That the basalts are contaminated is, therefore, unsurprising in that the magmas would have had to pass through continental crust. Interestingly, the nature of the contaminant changes from the Lower to the Middle Series (Fitton et al., Chap. 29, 
this volume). The lower lavas of the Lower Series are contaminated by low ${ }^{87} \mathrm{Sr} /{ }^{86} \mathrm{Sr}$, low $\varepsilon \mathrm{Nd}$, and low ${ }^{208} \mathrm{~Pb} /{ }^{204} \mathrm{~Pb}$ material, possibly granulite facies gneiss with very low time-integrated $\mathrm{Rb} / \mathrm{Sr}$. The nature of the contaminant progressively changed to a high ${ }^{87} \mathrm{Sr} /{ }^{86} \mathrm{Sr}$, high ${ }^{208} \mathrm{~Pb} / 204 \mathrm{~Pb}$ component in the Middle Series, which Fitton et al. (Chap. 29, this volume) have suggested to be amphibolite facies crust.

It is possible that the changing crustal component reflects a progressive shallowing of magma chambers, in which the assimilation/ contamination process occurs, from deep granulite crust to shallower (middle?) crust, although there are no a priori reasons why the lower and middle crusts need to be granulite and amphibolite, respectively (both rock types are found at different depths in the crust). Nonetheless this model is attractive. The assimilation of large proportions of crust to form the dacites of the Middle Series also implies that substantial volumes of mantle-derived magmas were introduced into the crust, either as large Moho magma chambers, or as shallower, midcrustal chambers (Fig. 15) (Larsen et al., Chap. 39, this volume).

\section{High-MgO Liquids}

The change in magmatic regime to produce the picrites and high$\mathrm{MgO}$ basalts of the Site 917 Upper Series may be coincident with breakup of the margin, thus allowing unimpeded flow of magmas through the lithosphere (Larsen, Saunders, Clift, et al., 1994; Fitton et al., 1995). The variable, but often high $\mathrm{MgO}$ content of these lavas, and the presence of skeletal, high-Fo olivines (e.g., Demant, this volume), indicate that some of the magmas were primary or near-primary picritic liquids that did not stall in magma bodies. Thy et al. (this volume) in their evaluation of the high-MgO flows suggest, however, that most are nonprimary in nature, having accumulated olivine phenocrysts.

High-MgO liquids have been inferred for several regions of the North Atlantic Igneous Province: Baffin Island (Clarke, 1970), West Greenland (Clarke and Pedersen, 1976), the Kangerlussuaq area of central East Greenland (Nielsen et al., 1981; Brooks and Nielsen, 1982), and the British Tertiary Igneous Province (e.g., Rum: Emeleus, 1987; Kent, 1995). Using olivine-liquid equilibria, Pedersen (1985) calculated that the $\mathrm{MgO}$ content of lavas in the Vaigat Formation, West Greenland, may have been as high as $19 \mathrm{wt} \%$ to 20 wt\%. Gill et al. (1992) extrapolated these data to estimate high-pressure liquidus temperatures (and source temperatures) of between $1540^{\circ} \mathrm{C}$ and $1600^{\circ} \mathrm{C}$ at depths of $60-90 \mathrm{~km}$ (assuming an entropy of melting of $250 \mathrm{~J} \mathrm{~kg}^{-1} \mathrm{~K}^{-1}$ ) The slightly less magnesian picrite of Unit $917-13$ gives a source temperature of about $1500^{\circ} \mathrm{C}$ at $60 \mathrm{~km}$, some $100^{\circ} \mathrm{C}$ hotter than ambient mantle (e.g., McKenzie and Bickle, 1988). All of these temperature estimates assume that the melting was anhydrous.

By the time of eruption of the basalts at Sites 915, 918, and 990 (Duncan, Larsen, Allan, et al., 1996), the MgO content of the erupted lavas had stabilized to values typical of N-MORB, suggesting that steady-state magma chambers had become established by that time. The slight contamination shown by the Site 915 basalt shows that the magmas were still in contact with continental crust, but this ceased before the eruption of the fully oceanic series at Site 918 . The crustal structure model proposed by Larsen et al. (Chap. 39, this volume) is consistent with the continental contamination observed at Site 915.

From the data presented in this volume, the period of eruption of the Lower and Upper Series at Site 917 sees an increase in the liquidus temperature of at least some of the melts (Thy et al., this volume) and, by implication, an increase in the potential temperature of the source. The absence of high- $\mathrm{MgO}$ liquids does not preclude hightemperature mantle, because these high density melts may stall and fractionate in magma chambers. It is possible, therefore, that the mantle at the time of the formation of the Lower and Middle Series at Site 917 was as hot as, or hotter, than the mantle supplying the Upper Series picrites; it is the tectonic regime that changed, allowing a higher proportion of the high-MgO melts to reach the surface unimpeded.

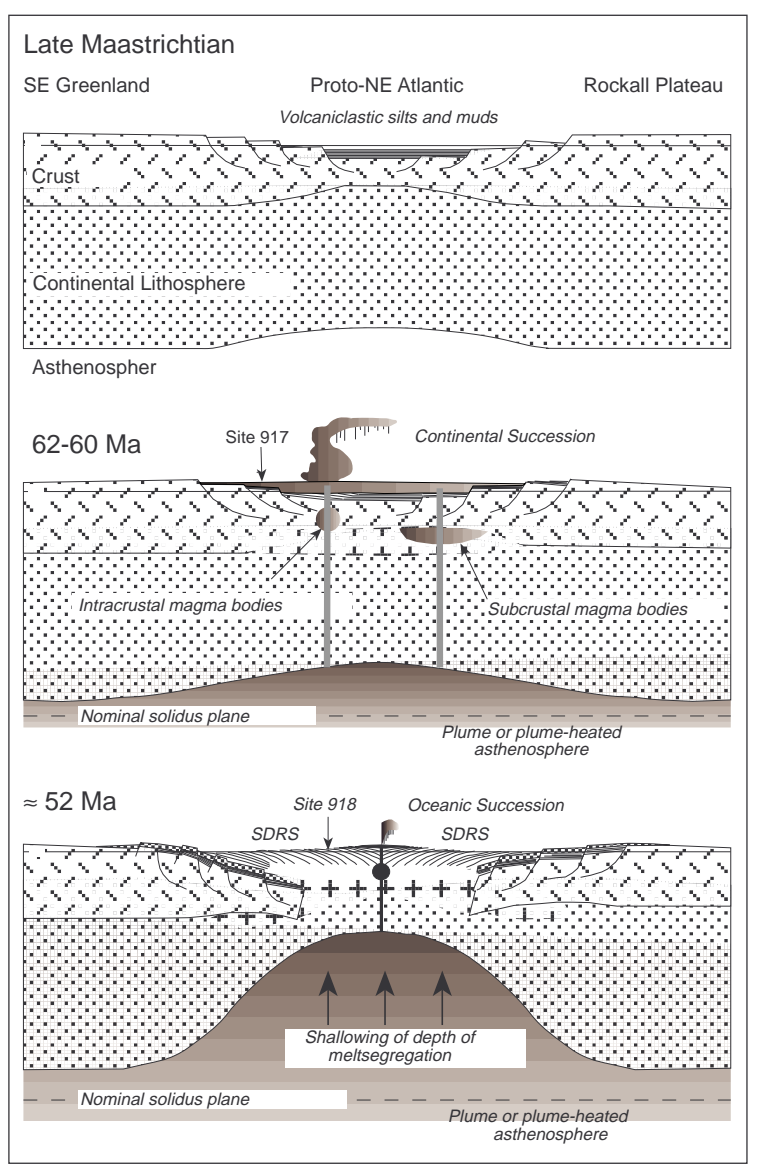

Figure 15. Schematic reconstructions of the southern northeast Atlantic at approximately $63^{\circ} \mathrm{N}$ during the Paleogene, showing the development of the rifted margin and the contemporaneous magmatism.

\section{Depth of Melt Segregation}

The lavas recovered during Leg 152 effectively bracket the main period of rifting and plate breakup. The Lower and Middle Series lavas from Site 917 (the Continental Succession), which show the greatest effects of contamination, predate the breakup, whereas those from Site 918 were erupted through and onto crust that was oceanic in character: there is no evidence for any continental involvement in the formation of these magmas. Basalt from Site 915 (and the more extensive cores from Site 990) do show evidence for crustal contamination (A.D. Saunders, J.G. Fitton, and P.D. Kempton, unpubl. data). Rifting and plate breakup should lead to a progressive shallowing of the top of the melt zone in the underlying mantle, as the overlying lithosphere was thinned.

The geochemical data corroborate this suggestion. The decreasing $\mathrm{Zr} / \mathrm{Sc}$ and $\mathrm{Sm} / \mathrm{Lu}$ of these basalts, especially within the Upper Series at Site 917 (Fig. 14), is entirely consistent with shallowing of the top of the melt zone (Fram et al., this volume). Some of this geochemical variation may be due to crustal contamination, or to changes in source composition. Unit 917-17, one of the more contaminated units from the Upper Series, has anomalously low Sm/Lu (Fig. 14). Many other samples from this unit, although showing high $\mathrm{Ba} / \mathrm{Nb}$ relative to the basalts from Site 918, and thus showing a small amount of crustal contamination, do not show a clear relationship between $\mathrm{Ba} / \mathrm{Nb}$ and $\mathrm{Sm} / \mathrm{Lu}$ (compare Figs. 8 and 14), suggesting that the variation in $\mathrm{Sm} /$ $\mathrm{Lu}$ is not, primarily, due to crustal contamination.

Studies of U-Th series disequilibrium in modern MORB indicates that melting beneath normal mid-ocean ridges begins at sufficient depth for garnet to be on the solidus (e.g., Beattie, 1993). This melt- 
ing continues to a high level, within the spinel stability field, thus diluting the effect of garnet. The presence of a lithospheric lid will curtail the dilution effect; the residual garnet signature is more clearly seen, and heavy-REE-depleted magmas will be produced. If the lithosphere is very thick, then melting may be prevented altogether. Hotter mantle will, however, begin to melt at greater depths, producing greater volumes of magma than cooler mantle, for a given lithospheric thickness. In the case of the southeast Greenland Margin, the Lower Series lavas, with high $\mathrm{Sm} / \mathrm{Lu}$ and $\mathrm{Zr} / \mathrm{Sc}$, were produced by melting within the garnet stability field, consistent with the lid effect (Fram et al., this volume; Fitton et al., Chap. 28, this volume). The average depth of melting decreased during emplacement of the Upper Series magmas, and decreased further by the time that the Hole 915A and 918 basalts were erupted. Note, however, that these data do not provide any constraints about the depth of the base of the melting column, which may have remained constant during the eruption of all of the Leg 152 lavas. The low $\mathrm{Zr} / \mathrm{Sc}$, and high absolute abundances of Sc in the 915 and 918 basalts, are entirely consistent with high degrees of predominantly shallow melting in the spinel stability field. However, the subaerial eruption of the Site 918 lavas, and the large amounts of melt that were involved in the production of the SDRS, imply hotter than ambient mantle temperatures, indicating that at least the lower parts of the melting column must have been in the garnet field.

Temporal changes in magma composition are observed locally in at least two other areas in the North Atlantic Igneous Province. Ellam (1992) and Kerr (1994) suggest that the heavy-REE-depleted patterns observed in Skye Main Lava Series and the Mull Plateau Group (Scotland) were generated below a lithospheric lid that was at least $60-80 \mathrm{~km}$ thick and restricted melting to a source region containing garnet. Later, more extensive melting of a similar source beneath thinner lithosphere $(<60 \mathrm{~km})$, entirely within the spinel lherzolite stability field, resulted in the relatively flat heavy REE patterns of the Fairy Bridge/Coire Gorm and Preshal More/Central Mull Tholeiite types. A similar shift in chemistry is observed in the Antrim Lavas (when passing from the Lower Formation to the Causeway Member of the Middle Formation [Barrat and Nesbitt, 1996]). Fram and Lesher (1993) have shown shallowing of average depth of melting in the North Atlantic Igneous Province as a whole, which again is consistent with models of pre- and post-breakup magmatism.

\section{Influence and Composition of the Iceland Plume}

An outstanding goal of recent geochemical and geophysical investigations has been an understanding of the structure, composition, and evolution of mantle plumes. Are plumes chemically zoned? What is their thermal structure? Is the thermal plume fully coupled to the compositional plume, or are they surrounded by an annulus of heated asthenospheric mantle? Where do plumes originate, and how do they initiate? We will start by focusing on the compositional aspects. Most plumes are located beneath a lithospheric lid, which tends to restrict melting to moderate to high pressures (e.g., Ellam, 1992). Consequently, the melts that are tapped (and ultimately erupt to form ocean islands and other intraplate provinces) provide an unrepresentative sample of the mantle. In the North Atlantic, however, the Iceland plume is ascending close to the Mid-Atlantic Ridge (MAR), and the magmas erupted along this ridge segregate at lower pressures than they would if a thick lithospheric lid were present. They thus provide a more robust sample of the plume and surrounding mantle. Furthermore, rather than looking at a point source, as on an intraplate ocean island, the magmas provide information from a traverse, more than $1000 \mathrm{~km}$ long, across virtually the entire plume.

As mentioned above, basalts from Rockall-Hatton Bank are lightREE-depleted, and closely resemble N-MORB (Joron et al., 1984). Were these basalts derived directly from a compositional plume, or from N-MORB-like mantle that has been heated by the plume, or from ambient-temperature N-MORB-like mantle? Each of these options implies a concentric structure, or gradient (thermal and compo- sitional), within and around the plume. A compositional gradient exists along the present-day Reykjanes Ridge, to the southeast of Iceland (Hart et al., 1973; Schilling, 1973). Here, the isotopic and trace element "signature" of the Iceland plume progressively decreases until $60^{\circ} \mathrm{N}$, where the compositions of the basalt become indistinguishable from N-MORB. Leg 152 is located on a flow line from MAR $60^{\circ} \mathrm{N}$, so is close to the extrapolated boundary between the "plume" and "N-MORB-like" mantle, if the boundary was in the same relative position at about $60 \mathrm{Ma}$.

Before Leg 152, we therefore were able to anticipate several scenarios. In the first scenario, the basalts recovered during the leg would have a purely "Icelandic" signature. This would suggest that the Icelandic signature would die out radially along the Paleogene rift axis, toward Hatton Bank, where N-MORB were erupted. In addition, the Icelandic signature should die out with time along the mantle flow line, as the MAR at $60^{\circ} \mathrm{N}$ was approached (where N-MORB are currently erupted). In the second scenario, the basalts recovered during Leg 152 would be entirely N-MORB in character, thus suggesting that compositional characteristics seen in basalts erupted along the MAR at $60^{\circ} \mathrm{N}$ were preserved along that particular mantle flow line. Drilling closer to the plume axis (e.g., Site 988 during Leg 163) would be expected to recover Icelandic basalts. In the third scenario, both Icelandic basalts and N-MORB would be recovered. Initially, however, it is necessary to identify the Icelandic component: can we "fingerprint" the plume?

An extensive literature exists about the composition of Icelandic basalts and differentiates (e.g., Jakobsson, 1972; Jakobsson et al., 1978; Wood, 1978; Imsland, 1983; Steinthorsson et al., 1985; Óskarsson et al., 1985; Furman et al., 1991, 1995; Hémond et al., 1993). A wide range of compositions, from strongly light-REEdepleted picrites to moderately light-REE-enriched tholeiites, alkali basalts, trachytes, and rhyolites (Fig. 2) are erupted within the neovolcanic rift zones (defined as regions of crust formed since the Brunhes Chron, 0.7 Ma). Like those seen on other ocean islands, Icelandic basalts do not define a single isotopic composition, but form an array in isotope space (e.g., Zindler and Hart, 1986) (Fig. 10). Such an array cannot be generated by near-surface processes (for example, by assimilation of Icelandic crust), because the low $\varepsilon N d$ values require a component much older than Iceland. The range of $\mathrm{Pb}$-isotope ratios observed in Icelandic basalts is also difficult to explain by near-surface processes (e.g., Sun and Jahn, 1975).

It has long been recognized that the Icelandic basalts are generated from a mantle source that has undergone long-term depletion (Fig. 10) (e.g., Carter et al., 1978; O’Nions et al., 1977; Zindler et al., 1979; Hémond et al., 1993). Data for many picrites and tholeiites from the neovolcanic zones overlap with North Atlantic N-MORB compositions, but other samples, including basalts from the Snaefellsnes Peninsula, extend the Iceland data field to higher ${ }^{87} \mathrm{Sr} /{ }^{86} \mathrm{Sr}$ and lower $\varepsilon N d$ values. Although trace element ratios and abundances are affected by partial melting and high-level crystal fractionation, there is a clear correlation between trace element abundances and isotope ratios in Icelandic basalts (for example, $\mathrm{Zr} / \mathrm{Nb}$ and $\varepsilon \mathrm{Nd}$; Fig. 11), implying that the range of trace element patterns cannot be produced by partial melting processes alone. Thus, some of the range in REE profiles shown by Figure 2 must also be a reflection of source composition.

An implication of Figures 2, 10, and 11 is that the Iceland plume comprises at least two end members, a depleted and a less-depleted end member, defined by the picrites and alkali basalts, respectively (Hémond et al., 1993; Kerr et al., 1995). These two end members give rise to the magmas in the Icelandic neovolcanic zones, which erupt as a spectrum of compositional types. Storage of magma in large-volume reservoirs serves to homogenize this spectrum of compositions and camouflage the multi-component nature of the primary melts. Such homogenized melts occasionally generate flows large enough to escape the neovolcanic zones, and be preserved at the surface as the Icelandic crust spreads apart. Lavas erupted solely within the Neovolcanic zones normally subside, according to the Pálmason (1986) model of crustal accretion, and are not preserved at the sur- 
face. This may explain why the bulk of the Tertiary lava pile in Iceland has such a monotonous composition, in comparison with lava flows from the neovolcanic zones (Hardarson and Fitton, 1994).

The depleted end member superficially resembles N-MORB, but Thirlwall et al. (1994) and Thirlwall (1995) have shown that Icelandic basalts and picrites have higher ${ }^{208} \mathrm{~Pb} /{ }^{204} \mathrm{~Pb}$ at a given ${ }^{207} \mathrm{~Pb} /{ }^{204} \mathrm{~Pb}$ than North Atlantic N-MORB (this can be seen on Fig. 12). It is virtually impossible to distinguish the two on the basis of REE alone, however. Fitton et al. (Chap. 28, this volume; in press) have developed a diagram that utilizes the relatively high $\mathrm{Nb}$ content found in many ocean island basalts, including those from Iceland, to distinguish depleted N-MORB from depleted Icelandic basalts. A plot of $\mathrm{Nb} / \mathrm{Y}$ vs. $\mathrm{Zr} / \mathrm{Y}$ shows a distinction between light-REE-depleted $\mathrm{N}$ MORB and light-REE-depleted Icelandic lavas (Fig. 16). The latter fall within a clearly defined array, above the N-MORB field. It would appear from this diagram that the depleted end member is an intrinsic part of the Iceland plume, as suggested by Hémond et al. (1993), Thirlwall et al. (1994), and Kerr et al. (1995), with a history of depletion that is different from that experienced by the source of $\mathrm{N}$ MORB.

It could be argued that the light-REE-depleted character of many lavas from the Upper Series at Site 917 and from Sites 915 and 918 represent melting of N-MORB mantle (albeit at higher temperatures than under normal mid-ocean ridges) or depleted Icelandic mantle. Because of the altered state of the Leg 152 basalts, and because of their low absolute $\mathrm{Pb}$ abundances, it is very difficult to use $\mathrm{Pb}$ isotopes as a discriminant to distinguish these two sources. Some samples from Sites 918 and 917 fall in the Icelandic field on the basis of ${ }^{87} \mathrm{Sr} /{ }^{86} \mathrm{Sr}$ and $\varepsilon \mathrm{Nd}$, but these samples also plot close to the N-MORB field (Fig. 10).

$\mathrm{The} \mathrm{Nb} / \mathrm{Y}-\mathrm{Zr} / \mathrm{Y}$ diagram is useful here. The basalts from Sites 915 and 918 all fall within the Iceland array on Figure 15, suggesting that the source has a component from the ancestral Iceland plume. Similarly, the high $\mathrm{Nb} / \mathrm{Zr}$ lavas from the Lower Series at Site 917 also fall within the array, as would be predicted from the $\varepsilon N d$ data (Fig. 11). Basalts and picrites from the Upper Series at Site 917 fall below the array, in the N-MORB field. The diagram is reasonably robust against the effects of crustal contamination. Most continental crustal rocks plot below the Iceland array, toward high $\mathrm{Zr} / \mathrm{Y}$, so addition of crust to a N-MORB-type magma tends to drive the composition away from, and below, the Iceland array. Note that those samples from the Upper Series at Site 917, which show evidence of contamination on the basis of ${ }^{87} \mathrm{Sr} /{ }^{86} \mathrm{Sr}, \varepsilon \mathrm{Nd}$, and REE patterns, still remain in the NMORB field (but displaced to slightly higher $\mathrm{Zr} / \mathrm{Y}$ ). On the basis of this diagram, none of the Site 917 Upper Series lavas has an Icelandic character, indicating that the light-REE-enrichment seen in some units may be due to crustal contamination, rather than a mantle signature as suggested by Fram et al. (this volume). Many samples from the Middle Series, and several of the low $\mathrm{Nb} / \mathrm{Zr}$ samples from the Lower Series at Site 917, show clear effects of contamination, and lie on a mixing line between N-MORB and Archean gneiss (Fitton et al., Chap. 28, this volume).

Fitton et al. (Chap. 28, this volume) plot other samples from the North Atlantic Igneous Province on this diagram. The samples from Hatton Bank/Rockall Plateau, which, like the basalts from Site 918, are strongly light-REE-depleted, fall in the N-MORB field, as do light-REE-depleted basalts from the Faeroes and from West Greenland. Basalts from the Upper Series at Site 642 on the Vøring Plateau straddle the Icelandic and MORB fields (Fig. 16). Samples from Sites 407, 408, and 409 in the Irminger Basin all plot within the Iceland field, as predicted from their positions on a mantle flow line from the Reykjanes Ridge (Fitton et al., Chap. 28, this volume).

The observation that the lavas from Hatton Bank plot within the field of N-MORB is reassuring, inasmuch as it confirms that the $\mathrm{Nb}$ / $\mathrm{Y}-\mathrm{Zr} / \mathrm{Y}$ diagram is not a result of melting conditions. It might be argued, for example, that melting of hot N-MORB-like mantle (e.g., mantle that was entrained in a plume) could replicate depleted Icelandic compositions, simply because of the changing topology of the
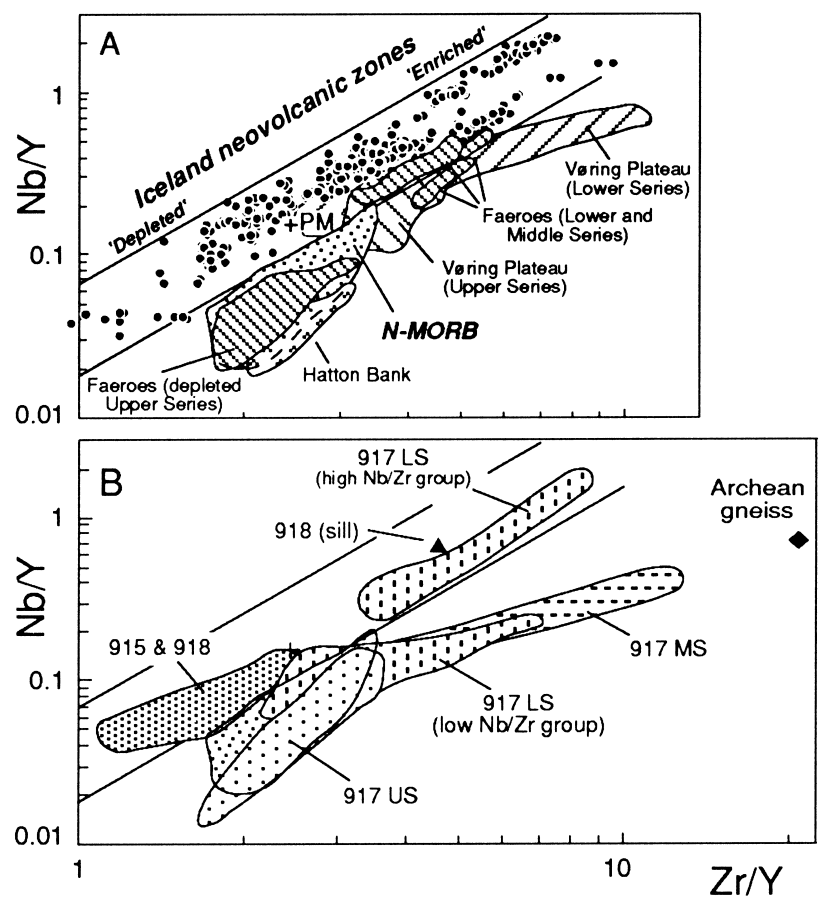

Figure 16. $\mathrm{Nb} / \mathrm{Y}$ vs. $\mathrm{Zr} / \mathrm{Y}$ for lavas (basalts and dacites) from (A) the North Atlantic Igneous Province and (B) Leg 152 lavas. Data sources: Iceland = Fitton et al. (this volume and references therein); Hatton Bank = Brodie and Fitton (this volume); Vøring Plateau = Viereck et al. $(1988,1989)$; Faeroes = Gariépy et al. (1983); N (Normal) MORB = unpublished data of the authors.

melt regime. However, the basalts from Hatton Bank and the Upper Series on the Faeroes were, presumably, generated from mantle that was hotter than ambient (elevated land surface; large volumes of magma), but have preserved a N-MORB signature. We can be confident that the $\mathrm{Nb} / \mathrm{Y}-\mathrm{Zr} / \mathrm{Y}$ relationships shown in Figure 16 do reflect variation in source composition.

The data confirm that the Iceland plume-or mantle that was chemically and isotopically similar to the Iceland plume-was involved in the formation of the basalts drilled on the southeast Greenland Margin. Even samples that are light-REE depleted, and superficially resemble N-MORB, have an Icelandic character. Samples from the Site 917 Upper Series, however, resemble N-MORB, although some samples are contaminated by crust. The magmas that were parental to the low $\mathrm{Nb} / \mathrm{Zr}$ Lower Series lavas were probably also NMORB-like, but their chemistry has been affected by crustal contamination. The compositional data are consistent with the evidence from the large volumes of magma, the subsidence history of the margin (Clift et al., 1995), and the presence of magnesian liquids, that the margin was underlain by hot mantle during the Paleogene.

These data, combined with those from other areas in the North Atlantic Igneous Province, are incompatible with models that deny a role for a mantle plume. Enhanced mantle convection beneath the developing rift axis may account for the formation of the thick sequences of SDRS basalts and underplated magmas (Mutter et al., 1988), but it is difficult to see how this model, alone, could account for the production of basalts with an Icelandic signature, rather than N-MORB. There are two additional problems with this model. First, it is difficult to see how enhanced convection could produce the pre-breakup magmas preserved in the Lower and Middle Series at Site 917 (and the contemporaneous basalts found elsewhere in the province). Second, it cannot readily account for the high- $\mathrm{MgO}$ melts that are common during the early stages of magmatism. The "hot cell" model of Anderson et al. (1992) has similar problems.

At the time of plate rifting and separation, the Vøring and the southeast Greenland Margins were approximately equidistant from 
the ancestral plume axis, whether White and McKenzie's (1989) or Lawver and Müller's (1994) estimated location of the axis is used (Fig. 3) (the southeast Greenland Margin transect lies closer to the White and McKenzie plume axis than does the Vøring transect). However, the precise location of the plume axis is open to some doubt. Lawver and Müller's (1994) estimate is based on plate reconstructions, whereas White and McKenzie's follows earlier workers (e.g., Brooks, 1973) in placing the hotspot axis close to the thick sequences of basalt in central East Greenland. Drilling on both the southeast Greenland and Vøring Margins, however, sampled basalts that have an Icelandic character; they are distinct from the Hatton Bank/Rockall Plateau basalts, which are indistinguishable from NMORB. The Hatton Bank transect is close to the limit of the physical manifestation of the plume (i.e., the SDRS), and implies that the basalts were derived from N-MORB mantle forming a concentric annulus around the compositional plume. That N-MORB-type mantle was also entrained within the plume is suggested by the presence of $\mathrm{N}$ MORB-like basalts in the Upper Series in the Faeroes Basalt Lava Group (Gariépy et al., 1983).

Ion microprobe trace element data show that basaltic tephra are similar to Icelandic basalts (Clift and Fitton, this volume). The majority of analyzed samples fall within the field of Icelandic lavas on the $\mathrm{Nb} / \mathrm{Y}-\mathrm{Zr} / \mathrm{Y}$ plot, and the light-REE-enriched profiles are encompassed by the range of Icelandic basalts. Clift and Fitton (this volume) therefore conclude that the trace element characteristics of the tephra are consistent with derivation from a mantle source similar to that presently beneath Iceland, but there is a greater range of enrichment, as indicated by $\mathrm{Zr} / \mathrm{Nb}$, than in basalts of a similar range of ages (up to $14 \mathrm{Ma}$ ). For example, the analyzed tephra show a greater range of $\mathrm{Zr} / \mathrm{Nb}(4-15)$ than the lavas of the Tertiary sequences (6-11.5), although not as extreme as the lavas found in the neovolcanic rift zones (5-36). This is broadly consistent with models of crustal formation in Iceland, whereby the more diverse, low-volume lavas are restricted to the rift zones, and large, more homogeneous lavas escape onto the rift margins. The lavas in the rift zones then subside to depth, and are unavailable for sampling, whereas the more distal flows remain close to the surface (e.g., Pálmason, 1986; Hardarson and Fitton, 1994). Thus, the ashes reflect the diversity of contemporaneous rift zone eruptions more faithfully than the Tertiary lava piles.

\section{Plume Impact or Incubation?}

Leg 152 has provided an important clue about the initiation of plume-related magmatism. It is now evident that the activity associated with the North Atlantic Igneous Province began at approximately $62 \mathrm{Ma}$. Most important is the realization that initiation of igneous activity was more or less synchronous over a wide area, from West Greenland (60-60.5 Ma: Storey et al., 1996), southeast Greenland (61 Ma: Sinton and Duncan, this volume; Werner et al., this volume); central East Greenland ( $\approx 60 \mathrm{Ma}$ : Storey et al., 1996), and the British Tertiary Igneous Province (62 Ma: Pearson et al., 1996) (see Fig. 7 and references therein). In many of these areas, the early activity was characterized by the eruption of high- $\mathrm{MgO}$ basalts and picrites and, by implication, high-temperature magmas (e.g., McClurg, 1982; Gill et al., 1992; Kerr, 1995; Fram and Lesher, 1997; Thy et al., this volume).

This early episode of magmatism was termed Phase 1 by Saunders et al. (in press), to distinguish it from the main Phase 2 magmatism (post $56 \mathrm{Ma}$ ) that accompanied plate breakup and continues to the present day in Iceland. The Phase 1 magmatism appears to be in response to the arrival of hot plume mantle that rapidly spread laterally; presumably the high temperature (required for picrite formation) and low viscosity of this mantle would enhance rapid dispersal. Perhaps this hot mantle was emplaced as a thin horizontal sheet, as suggested by Saunders et al. (in press) and Larsen and Saunders (this volume). The dispersal of this material would entail phenomenally high mantle flux rates. During the Paleocene, Baffin Island, the location of the most westerly of the known outcrops of Paleocene basalt, was located some $2000 \mathrm{~km}$ from the British Isles. Assuming that the plume ascended with an axisymmetric form, had an initial, preimpact diameter of $500 \mathrm{~km}$, and was equidistant from the United Kingdom and Canada, then the mantle would need to flow approximately $750 \mathrm{~km}$ within less than $2 \mathrm{~m}$.y. This equates to an average mantle flux rate of $0.4 \mathrm{~m} / \mathrm{y}$. The initial flux rates would be substantially higher than this, because in an axisymmetric disk the rate of increase of the radius $(\mathrm{dr} / \mathrm{dt}$ ) varies as $1 / \mathrm{r}$. Alternatively, the plume may have arrived as a much larger body (cf. Richards et al., 1989; Griffiths and Campbell, 1990), or as a non-axisymmetric body (e.g., a vertical sheet), or the plume mantle may have been channelled by pre-existing lithospheric topography.

Whatever the initial topology of the plume, the Leg 152 data, combined with the increasing body of data from elsewhere in the North Atlantic Igneous Province, indicate that the onset of magmatism was accompanied by the arrival of a hot, buoyant body of mantle. Further support for this is provided by evidence of uplift in the region, although it is not clear how extensive, nor how laterally continuous, the uplift was. The uplift recorded in the Danian sediments in central East Greenland and in the Forties Field in the North Sea provides strong corroborative evidence for the development of a widespread thermal anomaly and resultant buoyant support of the lithosphere. The more distal effects of this anomaly are recorded in the subsidence history of the North Sea Basin, where there is evidence for a transient thermal pulse between about 65 and $60 \mathrm{Ma}$ (Nadin et al., 1995). Local uplift around several basins, such as the northern North Sea Basin and the Faeroe-Shetland Basin, is indicated by the input of clastic sediments into what previously had been low-energy depositional environments (Anderton, 1993). This uplift began in Danian times, reached its peak in the Thanetian (58-55 m.y. ago), and was followed in some areas by rapid subsidence (e.g., England et al., 1993; Turner and Scrutton, 1993). There is no clear indication, however, from the terrestrial deposits in the United Kingdom, whether strong uplift began significantly prior to basalt eruption. Paleogene uplift of the order of 300 to $1000 \mathrm{~m}$ is recorded by apatite fission tracks in sediments from the east Irish Sea Basin (Hardman et al., 1993). Post-Cretaceous uplift and tilting of western Scotland is recorded in the stratigraphy of the Inner Moray Firth Basin in eastern Scotland (Underhill, 1991), and this could be linked with the development of the proto-Iceland thermal anomaly and associated rifting in the west (Thomson and Underhill, 1993).

It is difficult to determine whether the Paleogene magmatism represents the initiation of the Iceland plume, or a temporary increase in an anomalously high mantle flux. Crucial to this argument is whether the Iceland plume trace can be detected prior to the Cenozoic. Lawver and Müller (1994) have argued that the Alpha Ridge and the flood basalt province in the high Arctic on Axel Heiberg Island represent Cretaceous precursors to the Paleogene activity of the North Atlantic igneous province, but compositional or age data are not as yet available to constrain this suggestion (Tarduno, 1996).

Across the North Atlantic Igneous Province as a whole, after the continental flood volcanism associated with the emplacement of the large body of hot mantle at about $62-58 \mathrm{Ma}$, there appears to have been a short hiatus until breakup and plate separation led to the Phase 2 activity: formation of the SDRS and, close to the plume axis, the Plateau basalts of the East Greenland flood basalts. Decompression melting of hot mantle, as discussed by White and McKenzie (1989), may have been assisted by enhanced convection, if hot mantle was able to flow laterally from beneath the continental lithosphere into the developing rift axis (Saunders et al., in press; Larsen and Saunders, this volume).

\section{CONCLUSIONS}

1. Excellent recovery of lavas-mainly basalt, but also including picrites and dacites-belonging to the Paleocene and Eocene SDRS on the southeast Greenland Margin was achieved at Site 917 on the 
continental margin, and at Site 918 on the continental rise. Limited recovery of basalt was also achieved at Site 915.

2. All of the lavas appear to have been erupted subaerially or possibly, in the case of some of the lavas of the Lower Series at Site 917, in shallow water. Subaerial eruption of the main sequence of SDRS (Site 918) indicates that subaerial seafloor spreading was operative, akin to the situation in present-day Iceland, and that buoyant support of the eruptive centers was provided by hotter-than-ambient mantle. These observations corroborate the results from Legs 81 and 104 on SDRS on the Rockall Plateau and Vøring Plateau.

3. An important result of Leg 152 was the recovery of 61-m.y.-old dacites and basalts at Site 917 . These ages are significantly older than expected (the magnetic lineations in this region indicate that the bulk of the SDRS belongs to Chron 24r) and extend the known area of Paleocene magmatism in the North Atlantic Igneous Province. It is unclear whether the 61-m.y.-old lavas predate the initiation of extension, but they do predate breakup. The age of the picritic Upper Series lavas from Site 917 is unknown.

4. The lavas testify to a dramatically changing regime of partial melting and magmatic plumbing as the margin evolved from a continental to an oceanic setting. Most of the Lower and Middle Series lavas from Site 917 are highly contaminated by continental crust (both amphibolitic and granulitic Archean rocks appear to have been involved); the extent of contamination decreased dramatically before the eruption of the Upper Series lavas, and disappeared altogether by the time that the Site 918 basalts were produced. Small amounts of crustal contamination are, however, detectable in some Upper Series basalts, and the basalt from Site 915 .

5. High $\mathrm{MgO}$ liquids are inferred for some units from the Lower Series and Upper Series at Site 917. The highest $\mathrm{MgO}$ liquids occur in the Upper Series, the parental liquids containing as much as $18 \%$ $\mathrm{MgO}$. Changing tectonic regime and magmatic plumbing, accompanying plate breakup, may have been responsible for the eruption of these magmas. The high $\mathrm{MgO}$ liquids corroborate models that advocate hot mantle beneath the rift zone.

6 . The depth of melt segregation shallowed markedly during the eruption of the Upper Series at Site 917. Such shallowing of melt segregation is entirely consistent with the rifting of the margin, and appears to have been changing most rapidly during the formation of the Upper Series basalts and picrites at Site 917. With the available data, we cannot ascertain whether the depth of the base of the melt column remained essentially constant during the formation of all of the Leg 152 lavas. It is regrettable that we have been unable to date the Upper Series lavas, as they would provide an important constraint on the age of plate thinning. This must be a target for future studies, when analytical methods might enable reliable dating of rocks or minerals with ultra-low potassium and argon contents.

7. The isotopic and trace element compositions indicate that the majority of the least crustally contaminated lavas were derived from a depleted mantle source (i.e, with low ${ }^{87} \mathrm{Sr} /{ }^{86} \mathrm{Sr}$, high $\varepsilon N d$, and low $\mathrm{La} / \mathrm{Sm})$. It is, however, difficult to prove unequivocally whether this depleted source is the same as that producing mid-ocean-ridge basalts, or is intrinsic to the Iceland plume. Trace element ratios, especially $\mathrm{Nb} / \mathrm{Y}$ and $\mathrm{Zr} / \mathrm{Y}$, suggest that the basalts from Sites 915 and 918 were all derived from depleted Icelandic mantle. On the other hand, the basalts from the Upper Series at Site 917, and most of the basalts from the Lower Series at Site 917, were derived from N-MORB-like mantle.

8. Leg 152 provided important pieces of information for our understanding the North Atlantic igneous province. They suggest that the ancestral Iceland plume was indeed active at this time; that the Paleocene igneous province was active along the southeast Greenland Margin, and that a widespread, and sudden, magmatic event commenced at about $62 \mathrm{Ma}$. This implies in turn that the mantle flux rates at this time were very high, perhaps indicating the arrival of a plume head or plume "blob." Whether it represents the initiation of the Ice- land plume, or merely an anomalous mantle flux that was preceded during the Cretaceous by a much lower mantle flux, is uncertain.

\section{ACKNOWLEDGMENTS}

This synthesis is intended to be a distillation of many of the contributions of ship-based and shore-based scientists who have worked on the Leg 152 material. We have endeavored to be as representative and accurate as possible. We thank everyone who assisted in the successful completion of the leg and the subsequent shore-based studies. The manuscript was improved by comments from Peter Clift, Ray Kent, Andrew Kerr, Lotte Melchior Larsen, and Peter Thy.

\section{REFERENCES}

Anderson, D.L., Zhang, Y.-S., and Tanimoto, T., 1992. Plume heads, continental lithosphere, flood basalts and tomography. In Storey, B.C., Alabaster, T., and Pankhurst, R.J. (Eds.), Magmatism and the Causes of Continental Break-up. Geol. Soc. Spec. Publ. London, 68:99-124.

Anderton, R., 1993. Sedimentation and basin evolution in the Paleogene of the Northern North Sea and Faeroe-Shetland Basin. In Parker, J.R. (Ed.), Petroleum Geology of Northwest Europe. Geol. Soc. Spec. Publ. London, 31.

Arndt, N.T., and Christensen, U., 1992. The role of lithospheric mantle in continental flood volcanism: thermal and geochemical constraints. $J$. Geophys. Res., 97:10967-10981.

Backman, J., 1984. Cenozoic calcareous nannofossil biostratigraphy from the northeastern Atlantic Ocean-Deep Sea Drilling Project Leg 81. In Roberts, D.G., and Schnitker, D., et al., Init. Repts. DSDP, 81: Washington (U.S. Govt. Printing Office), 403-428.

Barrat, J.A., and Nesbitt, R.W., 1996. Geochemistry of the Tertiary volcanism of Northern Ireland. Chem. Geol., 129:15-38.

Barton, A.J., and White, R.S., 1995. The Edoras Bank margin: continental break-up in the presence of a mantle plume. J. Geol. Soc. London, 152:971-974.

Beattie, P., 1993. Uranium-thorium disequilibria and partitioning on melting of garnet peridotite. Nature, 363:63-65.

Berggren, W.A., Kent, D.V., and Flynn, J.J., 1985. Jurassic to Paleogene, Part 2. Paleogene geochronology and chronostratigraphy. In Snelling, N.J. (Ed.), The Chronology of the Geological Record. Geol. Soc. London Mem., 10:141-195.

Berggren, W.A., Kent, D.V., Swisher, C.C., III, and Aubry, M.-P., 1995. A revised Cenozoic geochronology and chronostratigraphy. In Berggren, W.A., Kent, D.V., Aubry, M.-P., and Hardenbol, J. (Eds.), Geochronology, Time Scales and Global Stratigraphic Correlation. Spec. Publ.Soc. Econ. Paleontol. Mineral., 54:129-212.

Bott, M.H.P., and Gunnarsson, K., 1980. Crustal structure of the IcelandFaeroe Ridge. J. Geophys., 47:221-227.

Brooks, C.K., 1973. Rifting and doming in southern East Greenland. Nature Phys. Sci., 244:23-25.

Brooks, C.K., and Nielsen, T.F.D., 1982. The Phanerozoic development of the Kangerdlugssuaq area, East Greenland. Medd. Groenl., Geosci., 9:30.

Campbell, I.H., and Griffiths, R.W., 1990. Implications of mantle plume structure for the evolution of flood basalts. Earth Planet. Sci. Lett., 99:79-93.

Cande, S.C., and Kent, D.V., 1995. Revised calibration of the geomagnetic polarity timescale for the Late Cretaceous and Cenozoic. J. Geophys. Res., 100:6093-6095.

Carter, S.R., Evensen, N.M., Hamilton, P.J., and O'Nions, R.K., 1978. Neodymium and strontium isotopic evidence for crustal contamination of continental volcanics. Science, 202:743-747.

Clarke, D.B., 1970. Tertiary basalts of Baffin Bay: possible primary magma from the mantle. Contrib. Mineral. Petrol., 25:203-224.

Clarke, D.B., Muecke, G.K., and Pe-Piper, G., 1983. The lamprophyres of Ubekendt Island, West Greenland: products of renewed partial melting or extreme differentiation? Contrib. Mineral. Petrol., 83:117-127.

Clarke, D.B., and Pedersen, A.K., 1976. Tertiary volcanic province of West Greenland. In Escher, A., and Watt, W.S. (Eds.), Geology of Greenland. Geol. Surv. Greenl., 364-385.

Clift, P.D., Turner, J., and ODP Leg 152 Scientific Party, 1995. Dynamic support by the Icelandic plume and vertical tectonics of the northeast Atlantic continental margins. J. Geophys. Res., 100:24473-24486. 
Coffin, M.F., and Eldholm, O., 1992. Volcanism and continental break-up: a global complication of large igneous provinces. In Storey, B.C., Alabaster, T., and Pankhurst, R.J. (Ed.), Magmatism and the Causes of Continental Break-up. Geol. Soc. Spec. Publ. London, 68:17-30.

- 1993. Scratching the surface: estimating dimensions of large igneous provinces. Geology, 21:515-518.

, 1994. Large igneous provinces: crustal structure, dimensions, and external consequences. Rev. Geophys., 32:1-36.

Cohen, R.S., and O'Nions, R.K., 1982. The lead, neodynium and strontium isotopic structure of ocean ridge basalts. J. Petrol., 23:299-324.

Dagley, P., and Mussett, A. E., 1986. Paleomagnetism and radiometric dating of the British Tertiary Igneous province: Muck and Eigg. Geophys. J. R. Astron. Soc., 85:221-242.

Dickin, A.P., 1981. Isotope geochemistry of Tertiary igneous rocks from the Isle of Skye, N. W. Scotland. J. Petrol., 22:155-189.

1988. The North Atlantic Tertiary Province. In Macdougall, J.D. (Ed.), Continental Flood Basalts: Dordrecht (Kluwer Academic), 111149 .

Dickin, A.P., and Jones, N.W., 1983. Isotopic evidence for the age and origin of pitchstones and felsites, Isle of Eigg, NW Scotland. J. Geol. Soc. London, 140:691-700.

Dickin, A.P., Moorbath, S., and Welke, H.J., 1981. Isotope, trace element and major element geochemistry of Tertiary igneous rocks, Isle of Arran, Scotland. Trans. R. Soc. Edinburgh, 72:159-170.

Dixon, J.B., 1989. Kaolin and serpentine group minerals. In Dixon, J.B., and Weed, S.B. (Eds.), Minerals in Soil Environments (2nd ed.). Soil Sci. Soc. Am., 467-525

Donn, W.L., and Ninkovich, D., 1980. Rate of Cenozoic explosive volcanism in the North Atlantic Ocean inferred from deep sea cores. J. Geophys. Res., 85:5455-5460.

Doré, A.G., 1991. The structural foundation and evolution of Mesozoic seaways between Europe and the Arctic. Palaeogeogr., Palaeoclimatol., Palaeoecol., 87:441-492.

Duncan, R.A., Larsen, H.C., Allan, J.F., et al., 1996. Proc. ODP, Init. Repts., 163: College Station, TX (Ocean Drilling Program).

Eldholm, O., and Grue, K., 1994. North Atlantic volcanic margins: dimensions and production rates. J. Geophys. Res., 99:2955-2968.

Eldholm, O., Thiede, J., Taylor, E., et al., 1987. Proc. ODP, Init. Repts., 104: College Station, TX (Ocean Drilling Program).

Ellam, R.M., 1992. Lithospheric thickness as a control on basalt geochemistry. Geology, 20:153-156.

Elliot, T.R., Hawkesworth, C.J., and Grönvold, K., 1991. Dynamic melting of the Iceland plume Nature, 351:201-206.

Emeleus, C.H., 1987. The Rhum layered complex, Inner Hebrides, Scotland. In Parsons, I. (Ed.), Origins of Igneous Layering: Dordrecht (Reidel), 263-286.

England, R.W., Butler, R.H.W., and Hutton, D.H.W., 1993. The role of Paleocene magmatism in the Tertiary evolution of basin on the NW seaboard. In Parker, J.R. (Ed.) Petroleum Geology of Northwest Europe. Geol. Soc. Spec. Publ. London, 97-105.

Evans, A.L., Fitch, F.J., and Millar, J.A., 1973. Potassium-argon age determinations on some British Tertiary igneous rocks. J. Geol. Soc. London, 129:419-443.

Fitton, J.G., Saunders, A.D., Larsen, L.M., Fram, M.S., Demant, A., Sinton, C., and Leg 152 Shipboard Scientific Party, 1995. Magma sources and plumbing systems during break-up of the Southeast Greenland margin: preliminary results from ODP Leg 152. J. Geol. Soc. London, 152:985990

Fitton, J.G., Saunders, A.D., Norry, M.J., and Hardarson, B.S., in press. Thermal and chemical structure of the Iceland plume. Earth Planet. Sci. Lett.

Fowler, S.R., White, R., Spence, G.D., and Westbrook, G.K., 1989. The Hatton Bank continental margin-II. Deep structure from two-ship expanding spread seismic profiles. Geophys. J., 96:295-310.

Fram, M.S., and Lesher, C.E., 1993. Geochemical constraints on mantle melting during creation of the North Atlantic basin. Nature, 363:712715

, 1997. Generation and polybaric differentiation of East Greenland Early Tertiary flood basalts. J. Petrol., 38:231-275.

Furman, T., Frey, F.A., and Park, K.H., 1991. Chemical constraints on the petrogenesis of mildly alkaline lavas from Vestmannaeyjar, Iceland; the Eldfell (1973) and Surtsey (1963-1967) eruptions. Contrib. Mineral. Petrol., 109:19-37.

1995. The scale of source heterogeneity beneath the Eastern neovolcanic zone, Iceland. J. Geol. Soc. London, 152:997-1002.
Gariépy, C., Ludden, J., and Brooks, C., 1983. Isotopic and trace element constraints on the genesis of the Faeroe lava pile. Earth Planet. Sci. Lett., 63:257-272.

Gill, R.C.O., Pedersen, A.K., and Larsen, J.G., 1992. Tertiary picrites in West Greenland: melting at the periphery of a plume? In Storey, B.C., Alabaster, T., and Pankhurst, R.J. (Eds.), Magmatism and the Causes of Continental Break-up. Geol. Soc. Spec. Publ. London, 68:335-348.

Goldschmidt-Rokita, A., Hansch, K.F.J., Hirschleber, H.B., Iwasaki, T., Kanazawa, T., Shimarura, H., and Sellevol, M.A., 1994. The ocean/continent transition along a profile through the Lofoten Basin, northern Norway. Mar. Geophys. Res., 16:201-224.

Griffiths, R.W., and Campbell, I.H., 1990. On the dynamics of long-lived plume conduits in the convecting mantle. Earth Planet. Sci. Lett., 103:214-227.

Hampton, C.M., and Taylor, P.N., 1983. The age and nature of the basement of southern Britain: evidence from $\mathrm{Sr}$ and $\mathrm{Pb}$ isotopes in some English granites. J. Geol. Soc. London, 140:499-509.

Hansen, H., Rex, D.C., Guise, P.G., and Brooks, C.K., 1989. ${ }^{40} \mathrm{Ar} /{ }^{39} \mathrm{Ar}$ ages on Tertiary East Greenland basalts from the Scoresby Sund area. Eos, 74:625.

Hardarson, B.S., and Fitton, J.G., 1994. Geochemical variation in the Tertiary basalts of Iceland. Mineral. Mag., 58A:372-373.

Hardman, M., Buchanan, J., Herrington, P., and Carr, A., 1993. Geochemical modelling of the East Irish Sea Basin: its influence on predicting hydrocarbon type and quality. In Parker, J.R. (Ed.) Petroleum Geology of Northwest Europe. Geol. Soc. Spec. Publ. London, 809-821.

Hart, S.R., Schilling, J.-G., and Powell, J.L., 1973. Basalts from Iceland and along the Reykjanes Ridge: Sr isotope geochemistry. Nature, 246:104107.

Hawkesworth, C.J., Mantovani, M., and Peate, D., 1988. Lithosphere remobilization during Paraná CFB magmatism. In Menzies, M.A., and Cox, K.G. (Eds.), Oceanic and Continental Lithosphere: Similarities and Differences: Oxford (Oxford Univ. Press), 205-223.

Hémond, C., Arndt, N.T., and Hofmann, A.W., 1993. The heterogeneous Iceland plume: Nd-Sr-O and trace element constraints. J. Geophys. Res., 98:15833-15850.

Hinz, K., 1981. A hypothesis on terrestrial catastrophes: wedges of very thick oceanward dipping layers beneath passive margins: their origin and paleoenvironmental significance. Geol. Jahrb., E22:3-28.

Imsland, P., 1983. Iceland and the ocean floor: comparison of chemical characteristics of the magmatic rocks and some volcanic features. Contrib. Mineral. Petrol., 83:31-37.

Ito, E., White, W.M., and Göpel, C., 1987. The O, Sr, $\mathrm{Nd}$ and $\mathrm{Pb}$ isotope geochemistry of MORB. Chem. Geol., 62:157-176.

Jakobsson, S.P., 1972. Chemistry and distribution patterns of Recent volcanic rocks in Iceland. Lithos, 5:365-386.

Jakobsson, S.P., Johnson, J., and Shido, F., 1978. Petrology of the western Reykjanes Peninsula, Iceland. J. Petrol., 19:669-705.

Joron, J.L., Bougault, H., Maury, R.C., Bohn, M., and Desprairies, A., 1984. Strongly depleted tholeiites from the Rockall Plateau margin, North Atlantic: geochemistry and mineralogy. In Roberts, D.G., Schnitker, D., et al., Init. Repts. DSDP, 81: Washington (U.S. Govt. Printing Office), 783-794.

Kent, R., 1991. Lithospheric uplift in eastern Gondwana: evidence for a long-lived mantle plume system? Geology, 19:19-23.

Kent, R.W., 1995. Magnesian basalts from the Hebrides, Scotland: chemical composition and relationship to the Iceland plume. J. Geol. Soc. London, 152:979-983.

Kerr, A.C., 1994. Lithospheric thinning during the evolution of continental large igneous provinces: a case study from the North Atlantic Tertiary province. Geology, 22:1027-1030.

1995. The geochemistry of the Mull-Morvern Tertiary lava succession, NW Scotland: an assessment of mantle sources during plumerelated volcanism. Chem. Geol., 122:43-58.

Kerr, A.C., Saunders, A.D., Hards, V.L., Tarney, J., and Berry, N.H., 1995. Depleted mantle plume geochemical signatures: no paradox for plume theories. Geology, 23:843-846.

Knox, R.W. and Morton, A.C., 1988. The record of early Tertiary N Atlantic volcanism in sediments of the North Sea Basin. In Morton, A.C., and Parson, L.M. (Eds.), Early Tertiary Volcanism and the Opening of the Northeast Atlantic. Geol. Soc. Spec. Publ. London, 39:407-419.

Knox, R.W.O., and Morton, A.C., 1983. Stratigraphical distribution of Early Palaeogene pyroclastic deposits in the North Sea Basin. Proc. Yorks. Geol. Soc., 44:355-363. 
Larsen, H.C., and Jakobsdóttir, S., 1988. Distribution, crustal properties and significance of seaward-dipping sub-basement reflectors off East Greenland. In Morton, A.C., and Parson, L.M. (Eds.), Early Tertiary Volcanism and the Opening of the Northeast Atlantic. Geol. Soc. Spec. Publ. London, 39:95-114.

Larsen, H.C., and Marcussen, C., 1992. Sill-intrusion, flood basalt emplacement and deep crustal structure of the Scoresby Sund region, East Greenland. In: Storey, B.C., Alabaster, T., and Pankhurst, R.J. (Eds.), Magmatism and the Causes of Continental Break-up, Spec. Publ., 68, Geol. Soc. (London), 365-386.

Larsen, H.C., Saunders, A.D., Clift, P.D., et al., 1994. Proc. ODP, Init. Repts., 152: College Station, TX (Ocean Drilling Program).

Larsen, H.C., Sawyer, D.S., and the NARM-DPG, 1991. North Atlantic rifted margins detailed planning group report. JOIDES J., 3:24-26.

Larsen, L.M., Watt, W.S., and Watt, M., 1989. Geology and petrology of the Lower Tertiary plateau basalts of the Scoresby Sund region, East Greenland. Bull.-Groenl. Geol. Unders., 157:1-164.

Lawver, L.A., and Müller, R.D., 1994. Iceland hotspot track. Geology, 22:311-314.

Macintyre, R.M., and Hamilton, P.J., 1984. Isotopic geochemistry of lavas from Sites 553 and 555. In Roberts, D.G., Schnitker, D., et al., Init. Repts. DSDP, 81: Washington (U.S. Govt. Printing Office), 775-781.

Mahoney, J.J., 1988. Deccan Traps. In MacDougall, J.D. (Ed.), Continental Flood Basalts: Dordrecht (Kluwer Academic), 151-194.

McClurg, J.E., 1982. Petrology and evolution of the northern part of the Rhum ultrabasic complex [Ph.D. thesis]. Univ. of Edinburgh.

McDonough, W.F., and Sun, S.-S., 1995. The composition of the Earth. Chem. Geol., 120:223-253.

McKenzie, D.P., 1978. Some remarks on the development of sedimentary basins. Earth. Planet. Sci. Lett., 40:25-32.

McKenzie, D.P., and Bickle, M.J., 1988. The volume and composition of melt generated by extension of the lithosphere. J. Petrol., 29:625-679.

Merriman, R.J., Taylor, P.N., and Morton, A.C., 1988. Petrochemistry and isotope geochemistry of early Palaeogene basalts forming the dipping reflector sequence SW of Rockall Plateau, NE Atlantic. In Morton, A.C., and Parson, L.M. (Eds.), Early Tertiary Volcanism and the Opening of the NE Atlantic. Geol. Soc. Spec. Publ. London, 39:123-134.

Morgan, J.V., Barton, P.J., and White, R.S., 1989. The Hatton Bank continental margin. III: Structure from wide-angle OBS and multichannel seismic refraction profiles. Geophys. J. Int., 98:367-384.

Morton, A.C., and Taylor, P.N., 1987. Lead isotope evidence for the structure of the Rockall dipping-reflector passive margin. Nature, 326:381-383.

Mussett, A.E., 1984. Time and duration of Tertiary igneous activity of Rhum and adjacent areas. Scott. J. Geol., 20:273-279.

1986. ${ }^{40} \mathrm{Ar}-{ }^{39} \mathrm{Ar}$ step-heating ages of the Tertiary igneous rocks of Mull, Scotland. J. Geol. Soc. London, 143:887-896.

Mussett, A.E., Dagley, P., and Eckford, M., 1976. The British Tertiary Igneous Province: palaeomagnetism and ages of dykes, Lundy Island, Bristol Channel. Geophys. J. R. Astron. Soc., 46:595-603.

Mutter, J.C., Buck, W.R., and Zehnder, C.M., 1988. Convective partial melting, 1. A model for the formation of thick basaltic sequences during the initiation of spreading. J. Geophys. Res., 93:1031-1048.

Mutter, J.C., Talwani, M., and Stoffa, P.L., 1982. Origin of seaward-dipping reflectors in oceanic crust off the Norwegian margin by "subaerial seafloor spreading." Geology, 10:353-357.

Mutter, J.C., and Zehnder, C.M., 1988. Deep crustal and magmatic processes: the inception of seafloor spreading in the Norwegian-Greenland Sea. In Morton, A.C., and Parson, L.M. (Eds.), Early Tertiary Volcanism and the Opening of the NE Atlantic. Geol. Soc. Am. Spec. Publ., 39:3548.

Nadin, P.A., Kusznir, N.J., and Toth, J., 1995. Transient regional uplift in the Early Tertiary of the northern North Sea and the development of the Iceland plume. J. Geol. Soc. London, 152:953-958.

Nielsen, T.F.D., Soper, N.J., Brooks, C.K., Faller, A.M., Higgins, A.C., and Matthews, D.W., 1981. The pre-basaltic sediments and the lower basalts at Kangerdlugssuaq, East Greenland: their stratigraphy, lithology, paleomagnetism and petrology. Medd. Groenl., Geosci., 6:1-25.

Noble, R.H., Macintyre, R.M., and Brown, P.E., 1988. Age constraints on Atlantic evolution: timing of magmatic activity along the E Greenland continental margin. In Morton, A.C., and Parson, L.M. (Eds.), Early Ter- tiary Volcanism and the Opening of the North Atlantic. Geol. Soc. Spec. Publ. London, 201-214.

O’Nions, R.K., Hamilton, P.J., and Evensen, N.M., 1977. Variations in ${ }^{143} \mathrm{Nd} /{ }^{144} \mathrm{Nd}$ and ${ }^{87} \mathrm{Sr} /{ }^{86} \mathrm{Sr}$ in oceanic basalts. Earth Planet. Sci. Lett., 34:13-22.

Óskarsson, N., Steinthórsson, S., and Sigvaldason, G.E., 1985. Iceland geochemical anomaly: origin, volcanotectonics, chemical fractionation and isotope evolution of the crust. J. Geophys. Res., 90:10011-10025.

Pálmason, G., 1986. Model of crustal formation in Iceland, and application to submarine mid-ocean ridges. In Vogt, P.R., and Tucholke, B.E. (Eds.), The Western North Atlantic Region. Geol. Soc. Am., Geol. of North Am. Ser., M:87-98.

Parrott, R.J.E., 1976. ${ }^{40} \mathrm{Ar} /{ }^{39} \mathrm{Ar}$ dating on Labrador Sea volcanics and their relation to seafloor spreading [Master's thesis]. Dalhousie Univ., Halifax.

Parrott, R.J.E., and Reynolds, P.H., 1975. Argon 40/argon 39 geochronology: age determinations of basalts from the Labrador Sea area. Geol. Soc. Am. Bull., 7:835.

Pearson, D.G., Emeleus, C.H., and Kelley, S.P., 1996. Precise ${ }^{40} \mathrm{Ar} /{ }^{39} \mathrm{Ar}$ ages for the initiation of igneous activity in the Small Isles, Inner Hebrides and implications for the timing of magmatism in the British Tertiary Volcanic Province. J. Geol. Soc. London, 153:815-818.

Pedersen, A.K., 1985. Reaction between picritic magma and continental crust: early Tertiary silicic basalts and magnesian andesites from Disko, West Greenland. Bull Geol. Soc. Groenl., 152.

Piasecki, S., Larsen, L.M., Pedersen, A.K., and Pedersen, G.K., 1992. Palynostratigraphy of the lower Tertiary volcanics and marine clastic sediments in the southern part of the West Greenland Basin: implications for the timing and duration of the volcanism. Rapp. Groenl. Geol. Unders., 154:13-31.

Powell, A.J., 1988. A modified dinoflagellate cyst biozonation for latest Palaeocene and earliest Eocene sediments from the central North Sea. Rev. Palaeobot. Palaeontol., 56:327-344.

Ribe, N.M., Christensen, U.R., and Theißing, J., 1995. The dynamics of plume-ridge interaction, 1: Ridge-centered plumes. Earth Planet. Sci. Lett., 134:155-168.

Richards, M.A., Duncan, R.A., and Courtillot, V.E., 1989. Flood basalts and hot-spot tracks: plume heads and tails. Science, 246:103-107.

Roberts, D.G., Schnitker, D., et al., 1984. Init. Repts. DSDP, 81: Washington (U.S. Govt. Printing Office).

Saunders, A.D., Fitton, J.G., Kerr, A.C., Norry, M.J., and Kent, R.W., in press. The North Atlantic igneous province. In Coffin, M.F., and Mahoney, J.J. (Eds.), Large Igneous Provinces. Am. Geophys. Union., Geophys. Monogr.

Saunders, A.D., Storey, M., Kent, R.W., and Norry, M.J., 1992. Consequences of plume-lithosphere interactions. In Storey, B.C., Alabaster, T., and Pankhurst, R.J. (Eds.), Magmatism and the Causes of Continental Break-up. Geol. Soc. Spec. Publ. London, 68:41-60.

Schilling, J.-G., 1973. Iceland mantle plume: geochemical study of Reykjanes Ridge. Nature, 242:565-571.

1975. Azores mantle blob: rare-earth evidence. Earth Planet. Sci. Lett., 25:103-115.

1991. Fluxes and excess temperatures of mantle plumes inferred from their interaction with migrating mid-ocean ridges. Nature, 352:397403.

Schilling, J.-G., and Noe-Nygaard, A., 1974. Faeroe-Iceland plume: rare earth evidence. Earth Planet. Sci. Lett., 24:1-14.

Schönharting, G., and Abrahamsen, N., 1989. Paleomagnetism of the volcanic sequence in Hole 642E, ODP Leg 104, Vøring Plateau, and correlation with early Tertiary basalts in the North Atlantic. In Eldholm, O., Thiede, J., Taylor, E., et al., Proc. ODP, Sci. Results, 104: College Station, TX (Ocean Drilling Program), 911-920.

Sigurdsson, H., and Loebner, B., 1981. Deep-sea record of Cenozoic explosive volcanism in the North Atlantic. In Self, S., and Sparks, R.S.J. (Eds.), Tephra Studies: Dordrecht (Reidel), 289-316.

Soper, N.J., Downie, C., Higgins, A.C., and Costa, L.I., 1976a. Biostratigraphic ages of Tertiary basalts on the east Greenland continental margin and their relationship to plate separation in the northeast Atlantic. Earth Planet. Sci. Lett., 32:149-157.

Soper, N.J., Higgins, A.G., Downie, C., Matthews, D.W., and Brown, P.E., 1976b. Late Cretaceous-early Tertiary stratigraphy of the Kangerdlugs- 
suaq area, east Greenland, and the age of opening of the north-east Atlantic. J. Geol. Soc. London, 132:85-104.

Spence, G.D., White, R.S., Westbrook, G.K., and Fowler, S.R., 1989. The Hatton Bank continental margin, I. Shallow structure from two ship expanding spread profiles. Geophys. J., 96:273-294.

Staples, R.K., White, R.S., Brandsdottir, B., Menke, W.H., Maguire, P.K.H., McBride, J., and Smallwood, J., in press. Faero-Iceland Ridge Experiment - 1. The crustal structure of north-eastern Iceland. J. Geophys. Res.

Steinthorsson, S., Oskarsson, N., and Sigvaldason, G.E., 1985. Origin of alkali basalts in Iceland: a plate tectonic model. J. Geophys. Res., 90:10027-10042.

Storey, M., Duncan, R.A., Larsen, H.C., Pedersen, A.K., Waagstein, R., Larsen, L.M., Tegner, C., and Lesher, C.A., 1996. Impact and rapid flow of the Iceland plume beneath Greenland at $61 \mathrm{Ma}$. Eos, 77:F838.

Sun, S.-S., and Jahn, B., 1975. Lead and strontium isotopes in post-glacial basalts from Iceland. Nature, 255:527-530.

Talwani, M., Udintsev, G., et al., 1976. Init. Repts. DSDP, 38: Washington (U.S. Govt. Printing Office).

Tarduno, J.A., 1996. Arctic flood basalt volcanism: examining the hypothesis of Cretaceous activity at the Iceland hotspot. Eos, 77:F844.

Tarling, D.H., 1967. The palaeomagnetic properties of some Tertiary lavas from East Greenland. Earth Planet. Sci. Lett., 3:81-88.

Taylor, P.N., and Morton, A.C., 1989. Sr, Nd, and Pb isotope geochemistry of the upper and lower volcanic series at Site 642. In Eldholm, O., Thiede, J., Taylor, E., et al., Proc. ODP, Sci. Results, 104: College Station, TX (Ocean Drilling Program), 429-435.

Thirlwall, M.F., 1995. Generation of $\mathrm{Pb}$ isotopic characteristics of the Iceland plume. J. Geol. Soc. London, 152:991-996.

Thirlwall, M.F., Upton, B.G.J., and Jenkins, C., 1994. Interaction between continental lithosphere and the Iceland plume: $\mathrm{Sr}-\mathrm{Nd}-\mathrm{Pb}$ isotope geochemistry of Tertiary basalts, NE Greenland. J. Petrol., 35:839-879.

Thomas, J., 1996. The occurrence of the dinoflagellate cyst Apectodinium (Costa and Downie 1976) Lentin and Williams 1977 in the Moray and Montrose Gropus (Danian to Thanetian) of the UK central North Sea. In Knox, R.W.O., Corfield, R.M., and Dunay, R.E. (Eds.), Correlation of the Early Paleogene in Northwest Europe. Geol. Soc. Spec. Publ. London, 101:115-120.

Thompson, P., 1986. Dating the British Tertiary Igneous Province by the ${ }^{40} \mathrm{Ar} /{ }^{39} \mathrm{Ar}$ stepwise degassing method. [Ph.D. dissert.]. Univ. of Liverpool.

Thompson, P., Mussett, A.E., and Dagley, P., 1987. Revised ${ }^{40} \mathrm{Ar}-{ }^{39} \mathrm{Ar}$ age for granites of the Mourne Mountains, Ireland. Scott. J. Geol., 23:215220.

Thomson, K., and Underhill, J.R., 1993. Controls on the development and evolution of structural styles in the Inner Moray Firth Basin. In Parker, J.R. (Ed.), Petroleum Geology of Northwest Europe. Geol. Soc. Spec. Publ. London, 1167-1178.

Turner, J.D., and Scrutton, R.D., 1993. Subsidence patterns in western margin basins: evidence from the Faeroe-Shetland Basin. In Parker, J.R. (Ed.), Petroleum Geology of Northwest Europe. Proc. 4th Conf. Petrol. Geol., Geol. Soc. London, 2:975-983.

Underhill, J.R., 1991. Implications of Mesozoic-Recent basin development in the western Inner Moray Firth, UK. Mar. Petrol. Geol., 8:359-369.

Upton, B.G.J., 1988. History of Tertiary igneous activity in the N Atlantic borderlands. In Morton, A.C., and Parson, L.M. (Eds.), Early Tertiary Volcanism and the Opening of the NE Atlantic. Geol. Soc. Spec. Publ. London, 39:429-453.

Upton, B.G.J., Emeleus, C.H., Rex, D.C., and Thirlwall, M.F., 1995. Early Tertiary magmatism in NE Greenland. J. Geol. Soc. London, 152:959964.
Viereck, L.G., Hertogen, J., Parson, L.M., Morton, A.C., Love, D., and Gibson, I.L., 1989. Chemical stratigraphy and petrology of the Vøring Plateau tholeiitic lavas and interlayered volcaniclastic sediments at ODP Hole 642E. In Eldholm, O., Thiede, J., Taylor, E., et al., Proc. ODP, Sci. Results, 104: College Station, TX (Ocean Drilling Program), 367-396.

Viereck, L.G., Taylor, P.N., Parson, L.M., Morton, A.C., Hertogen, J., Gibson, I.L., and the ODP Leg 104 Scientific Party, 1988. Origin of the Palaeogene Vøring Plateau volcanic sequence. In Morton, A.C., and Parson, L.M. (Eds.), Early Tertiary Volcanism and the Opening of the Northeast Atlantic. Geol. Soc. Spec. Publ. London, 39:69-83.

Vink, G.E., 1984. A hotspot model for Iceland and the Vøring Plateau. J. Geophys. Res., 89:9949-9959.

Vogt, P.R. and Avery, O.E., 1974. Detailed magnetic surveys in the northeast Atlantic and Labrador Sea. J. Geophys. Res., 79:363-389.

Waagstein, R., 1988. Structure, composition and age of the Faeroe basalt plateau. In Morton, A.C., and Parson, L.M. (Eds.), Early Tertiary Volcanism and the Opening of the Northeast Atlantic. Geol. Soc. Spec. Publ. London, 39:225-238

Wallace, J.M., Ellam, R.M., Meighan, I.G., Lyle, P., and Rogers, N.W., 1994. $\mathrm{Sr}$ isotope data for the Tertiary lavas of Northern Ireland: evidence for open system petrogenesis. J. Geol. Soc. London, 151:869-877.

Walsh, J.N., Beckinsale, R.D., Skelhorn, R.R., and Thorpe, R.S., 1979. Geochemistry and petrogenesis of Tertiary granitic rocks from the Island of Mull, northwest Scotland. Contrib. Mineral. Petrol., 71:99-116.

White, R.S., 1992. Crustal structure and magmatism of North Atlantic continental margins. J. Geol. Soc. London, 149:841-854.

White, R.S., McBride, J.H., Maguire, P.K.H., Brandsdottir, B., Menke, W., Minshull, T.A., Richardson, K.R., Smallwood, J.R., Staples, R.K., and FIRE Working Group, 1996. Seismic images of crust beneath Iceland contribute to long-standing debate. Eos, 21:19200-19201.

White, R.S., and McKenzie, D., 1989. Magmatism at rift zones: the generation of volcanic continental margins and flood basalts. J. Geophys. Res., 94:7685-7729.

White, R.S., Spence, G.D., Fowler, S.R., McKenzie, D.P., Westbrook, G.K., and Bowen, A.N., 1987. Magmatism at rifted continental margins. Nature, 330:439-444.

Wolfe, C.J., Bjarnason, I.T., VanDecar, J.C., and Solomon, S.C., 1997. Seismic structure of the Iceland mantle plume. Nature, 385:285-247.

Wood, D.A., 1978. Major and trace element variations in the Tertiary lavas of eastern Iceland with respect to the Iceland geochemical anomaly. $J$. Petrol., 19:393-436

Ziegler, P.A., 1982. Geological Atlas of Western and Central Europe: Amsterdam (Elsevier).

Zindler, A., and Hart, S., 1986. Chemical geodynamics. Annu. Rev. Earth Planet. Sci., 14:493-571.

Zindler, A., Hart, S.R., and Frey, F.A., 1979. Nd and Sr isotope ratios and rare earth element abundances in Reykjanes Peninsula basalts: evidence for mantle heterogeneity beneath Iceland. Earth Planet. Sci. Lett., $45: 249-262$.

Date of initial receipt: 10 December 1996

Date of acceptance: 11 April 1997

Ms 152SR-239 